DIW BERLIN

Discussion

Papers

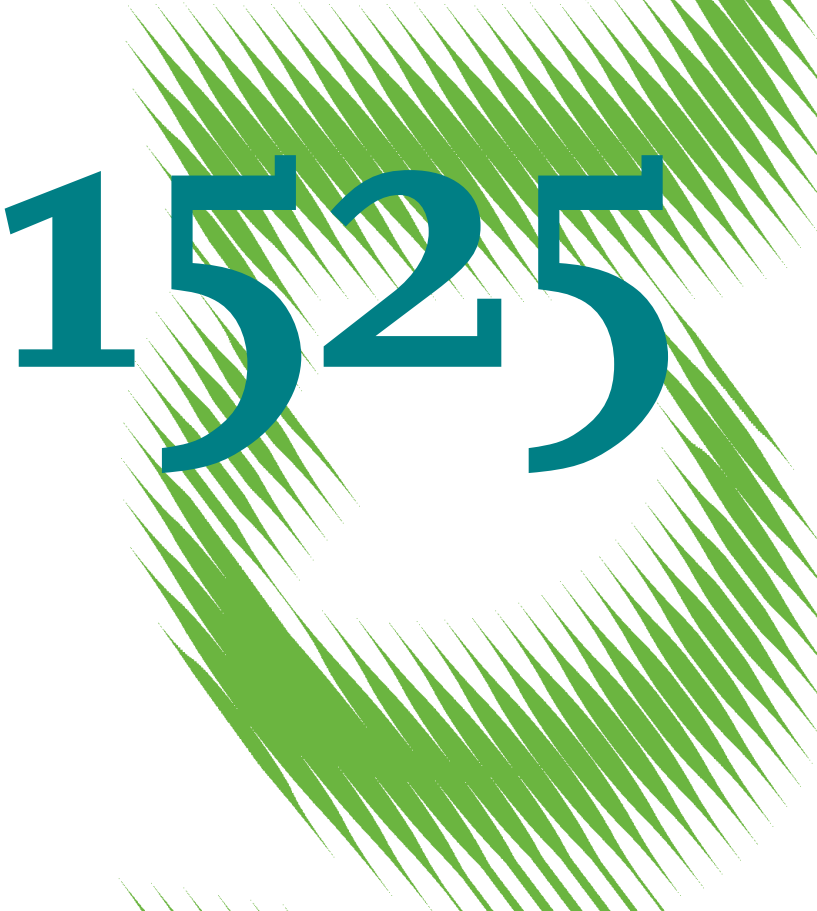

The Effect of Peer Observation on Consumption Choices

Experimental Evidence 
Opinions expressed in this paper are those of the author(s) and do not necessarily reflect views of the institute.

IMPRESSUM

(C) DIW Berlin, 2016

DIW Berlin

German Institute for Economic Research

Mohrenstr. 58

10117 Berlin

Tel. +49 (30) $89789-0$

Fax +49 (30) $89789-200$

http://www.diw.de

ISSN electronic edition 1619-4535

Papers can be downloaded free of charge from the DIW Berlin website:

http://www.diw.de/discussionpapers

Discussion Papers of DIW Berlin are indexed in RePEc and SSRN:

http://ideas.repec.org/s/diw/diwwpp.html

http://www.ssrn.com/link/DIW-Berlin-German-Inst-Econ-Res.html 


\title{
The Effect of Peer Observation on Consumption Choices: Experimental Evidence
}

\author{
Antonia Grohmann ${ }^{* 1}$ and Sahra Sakha ${ }^{\dagger 2}$ \\ ${ }^{1}$ German Institute for Economic Research \\ ${ }^{2}$ Deutsche Bundesbank
}

November 9, 2016

Updated Version

\begin{abstract}
This paper investigates the impact of peer observation on consumption decisions of rural households in Thailand using a lab-in-the-field experiment. We find that observing groups show lower within group standard deviation. Thus, we provide evidence for conformity. Further, we find that individual's consumption choice is influenced by the group choice controlling for large number of individual, household, and village characteristics. Concerning the mechanisms, we observe that unfamiliarity of the consumption good is counteracted by peer effects. We further show that the consumption choice is influenced by how many people made the same decision previously, but not by who made that decision.

JEL classification: D12, C21, C92

Keywords: Consumption, Peer Effects, Conformity

\footnotetext{
*International Economics, German Institute for Economic Research (DIW Berlin), Mohrenstrae 58, 10117 Berlin, Germany, Email: agrohmann@diw.de, Tel: +49 (30) 89789-436

${ }^{\dagger}$ Research Department, Deutsche Bundesbank, 60431 Frankfurt am Main, Email: sahra.sakha@bundesbank.de, Tel: +49 (69) 9566-8626

${ }^{1}$ We thank participants at the 2nd International Meeting on Experimental and Behavioral Social Sciences (IMEBESS), Network for Integrated Behavioral Science Conference (NIBS), Boulder Conference on Consumer Financial Decision Making, 2nd Annual Conference of the International Association for Applied Econometrics (IAAE), 30th Congress of the European Economic Association (EEA) and the German Economics Association (VfS) for helpful suggestions. In particular, we thank Colin Camerer, Esther Faia, Dimitris Georgarakos, Isabel Guenther, Rema Hanna, David Kiss, Stefan Klasen, Charles Manski, Lukas Menkhoff, Alistar Munro, Susan Steiner, Matthias Sutter, Dean Yang, and Juliane Zenker. Financial support by the German Research Foundation (DFG, grant RTG 1723) is gratefully acknowledged.
} 


\section{Introduction}

The feeling of buying something because someone else already has it is a feeling familiar to many. Despite anecdotal evidence that peers exert a very powerful influence over one's consumption behavior, proofing the existence of peer effects empirically poses some challenges. One reason is the difficulty in identifying peer effects. Measuring the extent to which peers affect decision-making is challenging, because social group formation is usually endogenous, meaning that observed peer effects may be due to individuals in a group being more similar than other individuals, which complicates causal inference. At the same time, peers often experience the same events or shocks, causing them to behave in a similar way (Manski, 1993). Hence, identifying peer effects based on most observational data is problematic.

So far, in the literature this problem is often solved though natural experiments (Sacedote 2001), through special types of data that allow identification through so called peers of peers (De Giorgi et al., 2010), or though laboratory experiments (Falk and Ichino, 2006). The first two solutions have the disadvantage that suitable data is very rare. The last has the disadvantage that those in peer groups usually do not know each other and that little is known about the respondents.

We here perform a novel lab-in-the-field experiment to study consumption choices in rural villages in Thailand. We conduct the experiment there because of the prevalence of close knit communities. In other words, even though assignment to a group is random; groups are made up of people that are familiar with each other since they live in the same village, and often have done so for many generations (Mangyo and Park, 2011). This allows us to study dynamic peer effects in a more natural environment, thus enhancing external validity, in particular compared to other laboratory experiments using complete strangers.

In addition, we are able to combine our lab-in-the-field experiment with a very extensive household survey that has been running for four waves, which means that we have a large amount of information about respondents, their household, and the village in which they live. Having a large amount of information about the respondents not only helps us to identify peer effects, but it 
also enables us to look deeper into the measured effects that often could not be identified in the experimental literature before. To the best of our knowledge, no lab-in-the-field experiment of this form studying the effect of peers on consumption has been performed.

The study of peer effects in consumption choices is not just crucial for further improving our understanding of individual decision-making, but it can also have an important effect on policy. If peer effects are present, cash transfer programs may influence those beyond the immediate target of the program (i.e. Angelucci and De Giorgi, 2009; Boneva, 2014). At the same time, policymakers interested in increasing the uptake of certain goods, such as health services or innovative technology could use peer effects to increase general consumption thereof.

In this paper, we aim to (i) identify the existence of peer effects in terms of consumption decisions; (ii) investigate some of the mechanisms through which peer effects operate; and (iii) test whether there are differences in the way certain people are affected by their peers.

The design of our experiment is straightforward: we test consumption choices by simply offering respondents the choice between a combination of sweet and savoury snacks, i.e. the temptation good (called the tasty treat or TT from hereon) or money across seven rounds. Temptation goods are defined as goods that provide the current self with positive utility, but negative utility to any future self. These are, for example, alcohol, cigarettes or as in our case unhealthy foods (Banerjee and Mullainathan, 2010). The amount of money offered increases by ten Baht in every round, while the TT remains the same. In the control group, respondents have to make their consumption choices on their own, isolated from the rest of the respondents. In the treatment group, each respondent still makes his/her own decision, but all respondents observe each other. Hence, the only difference between treatment and control group is peer observation and so any difference in outcome can be attributed to peer observation.

We focus in particular on the effect of peer observation on temptation goods, since consumption choices for temptation goods are particularly susceptible to the influence of peer effects, as shown, for instance, for alcohol consumption 
in social psychology (Gunter and Furnham, 1998; Steinberg and Cauffman, 1996). Another reason for choosing temptation goods is that there are no real economic or welfare need for the offered temptation goods. The idea behind this is that playing the game with goods that are necessities, such as items of daily use, may have confounding effects on the demand for the good compared to the money offered.

Our experimental study has a number of advantages that enable us to tackle the problems described by Manski $(1993,2000)$. We are able to solve the problem of correlated effects by randomizing the village in which the experiment is performed under peer observation. In addition, as we perform an experiment that lasts a short time, we are able to avoid problems caused by contextual or time-variant unobservables that affect all group members. In order to identify endogenous peer effects, we use a model with leave-out mean in which an individual's consumption choice is regressed on the mean of the group, excluding the individual himself (Angrist, 2013).

Our results are the following: We find that observing groups - those that sit in close proximity to each other - have a higher group minimum and a lower group maximum. Consequentially, the standard deviation for observing groups is lower than for those groups that simply played at the same time, but without peer observation.

In further analyses, we confirm this finding by showing that the group average, excluding the individual him/herself, has a positive and significant influence on the decisions made by the individual respondent. Most importantly, the effect is not significant when the experiment is performed in non-observing groups.

Next, we aim to explore the mechanisms behind this effect. There are two possible reasons for this; either the respondents believes that others in the group have better information or they are gaining some kind of psychological benefit from conforming to others. Although definite answers are not possible, we find evidence that unfamiliarity with the tasty treat is counteracted by peer observations - indicating some evidence for the first mechanism. We also show that the number of group members that previously switched away from the TT affects the likelihood of the individual also switching in the subsequent 
round. Interestingly, we find no evidence that the characteristics of those that switched in the previous round affects individuals.

We also look at treatment heterogeneities to analyze whether there is a difference in peer effects for individuals with different background characteristics. We show that those with the highest cognitive ability are less susceptible to peer effects. At the same time, we find that peer effects seem to be stronger for those living in small villages compared to those living in large villages.

This paper contributes to a growing literature on peer effects and consumption. Recent studies using observational data find that individuals increase their consumption expenditure when their neighbor becomes exogenously wealthier (Angelucci and De Giorgi, 2009; Kuhn et al., 2011; Roth, 2014; Boneva, 2014). Previous studies use exogenous group formation as an identification strategy to show that social interaction effects are also important in other domains. Sacerdote (2001), for example, uses the random assignment of college students to their respective dorms to analyze peer effects on education. Bandiera et al. (2010) and Mas and Moretti (2009) find a positive and significant relation between social interaction and work performance. Chetty et al. (2015) show that moving into more affluent neighborhoods, has a positive influence on the well-being of children.

Other papers use the existence of partially overlapping groups of peers to solve issues related to both reflection and correlated effects. The intuition is that partially overlapping groups generate peers of peers (or excluded peers) who act as instruments in the simultaneous equation model of social interactions, thus, solving the reflection problem. De Giorgi et al. (2010), for instance, show that the choice of a major is influenced by peers using this method.

Another alternative is to use an experimental design to causally measure peer effects. Using a lab experiment, Falk and Ichino (2006) find positive peer effects in terms of labor productivity. Using a similar setting, Baecker and Mechtel (2014) study the effect of peers on cheating behavior. Both studies use a highly controlled setting this raises questions of external validity. The study coming closest to ours is the experimental study by Clingingsmith and Sheremeta (2015). They investigate the effect of visibility and income on the demand for conspicuous goods. In a fully-controlled laboratory setting, they 
vary both whether the purchase of a physical product is publicly visible or kept private and whether the income used for purchase is linked to social status or randomly assigned. Similarly, Bougheas et al. (2013) find that risk taking is correlated between group members, when they consults, but in line with our results, do not find a difference in the average risk taken.

Our results also contribute to the literature on conformity which is defined as an intrinsic taste to follow others (Goeree and Yariv, 2010), driven by factors such as popularity, observational learning, information, esteem and respect (Bernheim, 1994), as well as inequality aversion (Fehr and Schmidt, 1999; Bolton and Ockenfels, 2000).

Evidence on the exact mechanism that underlies conformity is still rare. Bursztyn et al. (2014) show, using a carefully designed field experiment, that both information transmission between friends and social network externalities play a role in peer effects regarding the demand for financial products. Cai et al. (2009) look at an experiment with two treatments in a restaurant setting in order to distinguish the effect of social learning from the effect of salience.

The remainder of this article is organized as follows. In Section 2, we present our data, experimental design and discuss descriptive statistics. Group level results are reported in Section 3. Section 4 provides individual level results while further robustness tests are presented in Section 5. Section 6 concludes.

\section{Data}

\subsection{Household Survey Data and Sampling}

Our peer experiment was part of the larger household survey of the research project "Impact of shocks on the vulnerability to poverty: Consequences for development of emerging Southeast Asian economies" funded by the German Research Foundation, which has been conducted in three northeastern provinces of Thailand since 2007. It is important to note that all villages as well as respondents were randomly sampled for the household survey. Details concerning sampling and the household survey can be found in Appendix $\mathbf{A}$. In addition to the peer experiment, we also collected data on a number of variables to complement the household survey. Questions designed to measure 
cognitive ability and overconfidence were asked following the peer experiment (Details are reported in Appendix B.

\subsection{Experimental Design}

The peer experiment was conducted in August 2013 with a total of 521 respondents from 66 villages in Ubon Ratchathani, the largest of the three Thai provinces where the household survey is conducted. The experiment consists of a very simple choice task that required no previous knowledge and that was easy to implement and measure in the field with a rural sample (Details on the implementation and instructions of the experiment can be found in Appendix A. Each respondent has to choose between a tasty treat or a certain amount of money. The tasty treat consists of popular items that are widely known across the country - a can of Coca-Cola, a piece of custard cake, a small package of Lays Classic Potato Crisps, a bar of chocolate, and a small pack of candies. It had a value of 40 THB (approximately 1 Euro). We made sure that the tasty treat included both sweet and savory items so that it would appeal to a wide range of tastes.

In the first round the enumerator asks respondents whether they would like to choose the tasty treat or 10 Thai Baht (THB). Respondents have to express their choices to their assigned enumerator. Once the respondent has decided in that round, the enumerator moves to the next round. In the second round, the respondent has to choose between the tasty treat and 20 THB. This continues for a total of seven rounds, with the value of the cash increasing by 10 THB each round. In the last round the respondent has to choose between the tasty treat and 70 THB. In order to make the experiment as easy as possible to follow, we use showcards that display the amount of money they can chose. The tasty treat is also placed directly in front of each respondent. In round four there is no price difference between the two choices. After round four, it becomes increasingly unreasonable to choose the tasty treat because of the significant price difference. The enumerator records the decision in each round. We allowed switching back and forth. There were 24 respondents who switched twice and were dropped from later analysis.

Before the experiment, respondents were asked to estimate the price of the 
tasty treat. After their prediction, each respondent was informed that the tasty treat costs 40 THB in order to avoid information asymmetries concerning the value of the product.

Another important component of our experiment was that the respondents would receive the tasty treat immediately after the experiment while they had to wait for the money until the end of the session, thus enhancing temptation. Respondents were reminded that they had to stay after the experiment and answer further questions (risk attitude, financial literacy, overconfidence and cognitive ability). During the experiment, we made sure that the respondents did not receive any food or sweet beverages to drink. Time-discounting factors can largely be ignored since the seven rounds of choosing between the tasty treat and money only took about ten minutes. The full session including postexperimental questions lasted on average one hour.

Once all seven choices were made, one decision was randomly played out by picking a number between 1 to 7 from a non-transparent bag. In case the respondent picked number 3 and chose the tasty treat in round 3, she received the tasty treat immediately. In case, the respondent picked money in that round, the respondent would receive $30 \mathrm{THB}$ at the end of the survey. All particpants received 50 Baht as a show-up-fee at the end of the session. After the experiment, respondents were asked how much he/she would be willing to pay at most to receive the tasty treat.

For practical reasons we randomized into treatment and control group on the village level. In the control group, the tasty treat game was played individually and was conducted with 261 individuals in 66 groups. To avoid peer observation, we made sure that respondents were separated across the town hall so that they could neither hear nor see the choices of the other respondents. It is also unlikely that the decision of one respondent affects other respondents in the control group because individuals respond at different speeds. Futhermore, one tasty treat was always on display for each individual respondent (for details see Figure A.1.

The peer treatment was conducted with 260 individuals in 60 groups. The size of the group ranges from three to five people. The procedure of the treatment is the same as in the individual treatment with the sole exception that 
decisions were conducted in an environment with peer observation, so that respondents could see each other. Each respondent is still responsible for their own decision, but they have to sit next to each other while completing the experiment. As in the control group, all the instructions were read out loud and showcards were used to demonstrate the possible choices between tasty treat and money in each round. The same number of tasty treats were on display as there were respondents. The principal enumerator read out the instructions. In each round, each respondent would announce their choice out loud and the enumerator assigned to them would record their choice. After all respondents have made their choice, the group moves on to the next round (for details see Figure A.2. There is no particular order in which respondents announce their choices, thus creating a more dynamic and natural setting.

Our experimental design does not allow us to observe the specific order in which participants answer. Given our random assignment of individuals to play the game alone or in a group, we are able to create counterfactual groups out of those individuals that played the game at the same time as their peers, but without directly observing their peers. Thus, we have two types of groups - those that performed the experiment at the same time and same location directly observing each other and those that performed the experiment without observing each other. Hence, any difference in group outcomes can therefore be attributed to the only difference - peer observation.

\subsection{Descriptive Statistics}

Table 1 shows summary statistics of individual and village characteristics broken down by treatment and control group as well as p-values for the t-test and Wilcoxon rank-sum test. Panel A displays results for individual characteristics. Our sample consists of around $50 \%$ women, average age is 54 years and $83 \%$ of our respondents are married. They have low levels of education (less than six years on average) with an average household size of more than four members. The vast majority of respondents name farming as their main occupation, with the reminder consisting of government officials, business owners, students, and housewives. As this study uses edible goods for consumption, we 
also look at the body mass index (BMI). The average in our sample has a BMI of 23, which is within the normal BMI range according to the WHO. Despite considerable growth in rural Thailand over the last decades, the northeast is still relatively poor, which is reflected in the average rate of consumption and average household wealth.

In addition to standard socio-demographic variables, we also collected a number of variables designed to measure cognitive ability (details are in Appendix $\mathbf{B}$. Firstly, we asked respondents to answer six math-based questions. On average 3.6 out of 6 math questions were answered correctly. Numeracy shows a near normal distribution with $1.99 \%$ answering all incorrectly and only $4.81 \%$ correctly answering all six questions. Second, we asked respondents to name as many animals as they can in 60 seconds. The average number of animals named is 17.2; however the standard deviation for this measure is rather large at 6.86. The correlation between the two cognitive ability measures, numeracy test and word fluency is 0.355 (Spearman; p-value $<0.001$ ). Both tests capture similar, yet distinct, aspects underlying cognitive ability. Third, we follow the same procedure as Dohmen et al. (2010) and use a single combined measure of cognitive ability.

Finally, we also measure overconfidence of our respondents, by asking respondents to predict how many maths questions they answered corectly. We define a subject whose math prediction is higher than his/her actual score as overconfident, and a subject whose prediction is below her actual score is called underconfident. Using this measure, $37 \%$ of our sample are overconfident while $33 \%$ are underconfident.

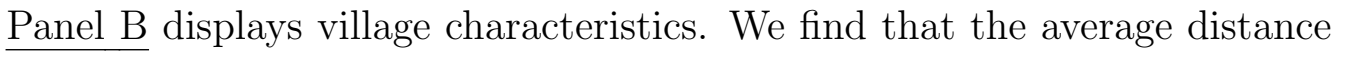
to the next district capital and to the provincial capital, Ubon, is $16 \mathrm{~km}$ and $60 \mathrm{~km}$ respectively. The average number of shocks 1 in our 66 villages was 1.45 ranging from 1 to 3 shocks in total. The number of households in a village varies significantly, ranging from 813 households in a village close to the provincial capital to only 55 households in a village that is also the furthest from Ubon, the provincial capital.

Table 1 also shows that randomization was successful and that there are no

\footnotetext{
${ }^{1}$ a shock is an adverse event that affects the village, such as flooding or changes to the infrastructure serving the village
} 
significant differences in observables between those that played the tasty treat game alone and those that played the game with peer observation. The only difference is that those who played in a group have, on average, more children which is statistically significant in the t-test and in the Wilcoxon rank-sum test. We control for this difference in further analysis.

As this study not only compares the behavior of individuals but also looks at the behavior of groups, it is important to check that group composition is the same between those that played in observing and non-observing groups. There are 126 groups in total with 60 observing groups and 66 non-observing groups. Table 2 shows that group means and group standard deviations are the same when looking at measured observables, with the exception of the number of children. Hence treatment and control groups are the same on average in composition and are equally alike. However, we also control for possible confounding effects in later regressions.

\section{Group Level Results}

\subsection{Comparing Groups}

We begin our analysis of the effects of peer observation by studying the difference between those groups that played the game observing each other and those that played the game at the same time and under the same conditions but without observation. T-tests and Wilcoxon-rank tests compare decisions between the two types of groups in Table $\mathbf{3}$. At first, it seems that there is no difference in the mean group choice of the last row that was chosen since the average last row chosen in both groups is the same.

We observe, however, a difference in the standard deviation in the last row of the tasty treat chosen between observing and non-observing groups. The standard deviation in the observing group is significantly lower than in the non-observing group. This is also reflected in the group minimum and the group maximum. The group minimum is the lowest switching point of anyone within the group, whereas the group maximum is the highest switching point within a group. We find that the group minimum is significantly higher and 
the group maximum is significantly lower when the experiment is performed with peers observing each other.

The finding is further supported in Table 4, where we control for both group means and group standard deviations of observables. Outcome variables stay the same as above (i.e. group mean, group minimum, group maximum, group standard deviation). The peer dummy is unity if the group played with peer observation. We confirm our finding from above - observing groups have lower standard deviation. The same can be seen when looking at the group minimum and maximum. The coefficient on the peer dummy is positive and significant in the regression estimating the group minimum and negative and significant in the regression estimating the group maximum. Interestingly, average group composition seems to have only a limited influence on the tasty treat choice. Groups with more women switch from tasty treat to money earlier. Similarly, there seems to be an effect of groups that are richer, i.e. that have higher average consumption.

In contrast, we find that the standard deviation of group observables seems to be linked to group outcomes. Specifically, we find that groups with higher standard deviations of cognitive ability seem to have higher mean switching rows and a higher group maximum. Interestingly, there seems to be a negative effect on the group maximum in groups with lower standard deviation in children. A negative and significant effect is also found for schooling, BMI, and overall well-being of the respondent in the column on the group minimum, but only at the $10 \%$ significance level for two of these cases. It should also be noted that group standard deviation of observables is not linked to standard deviation in choices. Hence our results in Table 3 are not driven by similarity in groups. Both Table 3 and Table 4 show that there is a significant difference in consumption choices between observing and non-observing groups. We find that consumption choices converge in observing groups. Hence, there is evidence for conformity when respondents observe each other.

Performing the experiment in a group seems to affect those that would have chosen the money early or those who decided to keep taking the tasty treat until later rounds. In Table 5 we again use t-test and Wilcoxon-rank tests to compare deciles between observing and non-observing groups. We find that the 
first and second decile in observing groups is higher than in the non-observing groups. The opposite can be seen when looking at the eighth and ninth decile. This is significantly higher in non-observing groups than in observing groups. This effect is stronger for the higher deciles. To conclude, it seems that peer observation particularly effects those that would have made extreme choices.

\subsection{Giving in to Temptation?}

We here briefly discuss our respondent's propensity to give in to temptation. This experiment was deliberately performed using temptation goods, as evidence, especially from social psychology (Gunter and Furnham 1998, Steinberg and Cauffman, 1996), suggests that demand for these goods is more likely to be influenced by the presence of peers. At the same time, we believe that playing the game with temptation goods and hence non-essential goods gives cleaner evidence of the effect of peer observation. It is possible that playing the game with other goods that can be considered necessities would have had a confounding effect on the choices made by individuals.

We here define giving in to temptations as choosing the tasty treat when the cash alternative is more than 40 THB, the TT's inherent price. From the tables discussed above, it could be inferred that subject do not give in to temptation. First, it seems that peer observation seems to prevent subjects from giving in to temptation since the mean of the average group choice for both the treatment and control group is just below three. Thus, the average respondent in both treatments switches from the amount of money offered well below the purchasing value of the tasty treat. The same applies to median choice, which lies just below three for both the treatment and the control groups. On the other hand, peer observation not only lowers the switching point of those that would otherwise have given in to temptation, but it also raises the switching point of those that would have switched very early. In other words, peer observation induces conformity, but does not change the decision in any particular direction. Hence, we do not find evidence that peer observation acts as a self-control mechanism against individual temptation. 


\section{Individual Level Results}

\subsection{Identification Strategy}

We are interested in identifying causal peer effects on individual decisionmaking and understanding whether consumption is affected by the observation of peers. The identification of peer effects, however, suffers from a number of econometric issues (Manski, 1993; Moffit,2001) which can be summarized into three categories: (a) correlated effects; (b) contextual effects; and (c) endogenous effects. Our experimental design (discussed in Section 2) represents an attempt to surmount the challenge of identifying a causal peer effect. Much of the literature following Manski focuses on the econometric issue of separating the causal peer effect from that of correlated unobservables (Miguel and Kremer, 2004; Bandiera and Rasul, 2006; Conley and Udry, 2010). Two ways of disentangling these effects are to (1) randomize the peers (Sacerdote, 2001; Duflo and Saez, 2003) or (2) randomize an intervention or new technology (Kremer and Miguel, 2007; Oster and Thornton, 2012; Godlonton and Thornton, 2012). We follow the first approach.

The double randomization in our experimental design, that is, randomly selecting households to perform the experiment given the sampling procedure and also randomizing peer and control treatments according to villages, circumvents the problem of correlated effects. Since we chose randomly who plays in a peer group and who is part of that peer group, there are unlikely to be any unobservables that would systematically influence the choices made by individuals. At the same time, our experiment takes place in a relatively controlled environment and only takes a short period of time. It is, hence, unlikely that unobservable time-variant characteristics influence decisions made by respondents.

To identify endogenous peer effects we use the so-called leave-out mean as the regressor in order to analyze the effect of the group average consumption on the individual consumption choice. While we are able to identify endogenous peer effects, we are not able to circumvent the reflection problem.

To identify the effect of peer observation, we will estimate the main regres- 
sion model in the following form using least squares estimation:

$$
y_{i j}=\beta \bar{y}_{-i, j}+\gamma \bar{x}_{-i, j}+\delta x_{i, j}+u_{i, j}
$$

In our framework, $y_{i j}$ is the consumption choice of tasty treat for individual $i$ who has group affiliation $j$ (observing or non-observing group). In our main analysis $y_{i j}$ will be the last row in which they choose the tasty treat before switching to money. The coefficient of interest is $\beta$, the coefficient on the group mean. The leave-out mean is previously used by Townsend (1994), Guryan et al. (2009), Duflo et al. (2011), Carrell et al. (2012) and discussed by Angrist (2014). In our analysis we split the sample between those performing the experiment in observing groups and those in non-observing groups. We expect $\beta$ to be positive when the experiment is performed with peer observation. When the experiment is, on the other hand, performed without peer observation we expect $\beta$ to be 0 .

We also include the variable $\bar{x}_{-i, j}$, which is the matrix average group socioeconomic characteristics in group $j$, excluding the individual $i . x_{i, j}$ is composed of a set of individual characteristics, such as female, age, schooling, log consumption, household size, dependency ratio, and BMI, that may affect consumption decisions. The error term $u_{i j}$ is clustered on the village level.

As we assign respondents randomly into peers groups, we assume $E\left(u_{i j} \mid x_{i j}\right)=$ 0 , i.e., no correlated effects or self-selection into groups. Thus, if we observe a difference in outcomes between observing and non-observing groups we can attribute this directly to the (on average) only difference between these groups, namely peer observation.

\subsection{Peer Effects}

As a next step, we look at peer effects and its effect on individual decisions, as described in the previous section. The outcome variable is the round when the individual switches from the TT to money. We find an effect of the group average on the individual consumption choice. Here we perform the regression using the above equation. Results are presented in Table 6. The first two columns cover the entire sample. We find that there is a significant and 
positive relationship between the average switching point in the group and individual's switching point. As this covers the entire sample, this could be caused by correlated effects. Hence, in the next four columns, we split out sample into those playing the game in observing groups and those playing it in non-observing groups (denoted as Peer and Single). In columns 3 and 4 we observe that the positive and significant relationship found in column 1 and 2 remains and is even stronger for the observing group. Columns 5 and 6 show the same regression, but for respondents playing the game without peer observation. Here the effect of the average peer choice has no effect on the individual's switching row. Similarly, in column 7 we introduce an interaction term between the group average and a dummy that takes the value one if the game was played in an observing group. The interaction term is positive and significant and so we can conclude that the relationship between the group average and the point of switching is not the same between observing and non-observing groups.

These results in Table 6 show that the peer effects observed in columns 3 and 4 above are not caused by unobserved correlated or contextual variables but rather by peers observing each other and making the same decision at the same time.

\subsection{Mechanisms}

So far, we find strong evidence for peer effects affecting consumption choices, thus causing conformity within a group. At the same time, we are able to show that individual decision-making is clearly influenced by the group's decision. However, it is not clear what the source of this group conformity is (information on the conceptual framework regarding conformity can be found in Appendix C.

The dynamic setting of our experiment allows us to gain a first insight into what may be the mechanism behind the observed peer effects. In the literature, a number of reasons behind peer effects are discussed (Bikhchandani et al., 1998; Cai et al.,2009). Here we look at two factors: Firstly, peer effects are argued to be caused by respondent's belief that others have better information 
(Foster and Rosenzweig, 1995; Miguel and Kremer, 2004; Conley and Udry, 2010; Oster and Thornton, 2012). Secondly, individuals could simply follow their peers because they are gaining some kind of network externality or benefit from doing what other people are doing (Moretti, 2011). Due to the design of our experiment, we are unable to provide definite answers. Nonetheless, these results provide some interesting insights.

Firstly, we discuss the role of information on peer effects. As described in Section 2, we asked respondent to estimate how much the tasty treat costs in a shop. We use this response as a proxy for how familiar the respondents are with the products. We construct a variable using the difference between the actual and estimate price. Then, we use this variable and create an interaction term with the leave-out-mean and add both to the regressions shown in Table 6. Results are shown in Table 7. Interestingly, unfamiliarity with the tasty treat makes the respondent less likely to choose it, but only in the single treatment. Not knowing the price of the product has no effect on the likelihood of choosing the tasty treat in the peer treatment. Hence, it seems possible that the effect of not knowing the product is counteracted by being able to observe one's peers and so information transfer seems to play a role in peer effects.

In order to look into the other possible mechanism, we look at the decision of respondents to switch in a certain round, depending on the proportion of his group that has switched in a previous round. We here try to find out whether the number of people that have switched previously has an effect on the likelihood of an individual switching. Table 8 shows results. The right hand variable is a dummy that is one if the respondent switches from the tasty treat to the money in a given round. The dependent variable is the proportion of people choosing the money i.e. had switched in previous rounds. Table 8 shows these regressions for both the single and the peer treatments, for the decision taken in rounds two through round four. Since most people only switch once, the regressions only include people that had not switched in previous rounds. We find that the proportion of people that had switched in the previous rounds has a positive effect on the likelihood that a respondent will switch from TT to money in a given round. However, this relationship 
breaks down after round three- possibly because the number of people that had not switched beforehand is very small.

In the next step, we investigate whether individual decisions are affected by not just the number of group members who have previously switched but who among the group members have switched. We test whether the likelihood of switching is increased if group members with certain characteristics (i.e. is old, wealthy, over-confident, intelligent) have switched in the previous round. We do not find any effects (details upon request). So it appears that the likelihood of switching is positively affected by how many people have switched previously, but not by who has switched previously. It has to be noted here that due to our experimental design it is possible that certain individuals within the group exert influence over other members, but we are not able to identify this through the choices individuals make in each round. Instead this influence may be more subtle, occurring between rounds. Similarly, it is possible that unobserved characteristics make some people follow others.

In this section we present evidence that both information and network externalities are behind peer effects. Unfamiliarity with a product seems to be counteracted by peer effects and at the same time the number of people in a group who have switched previously affects the likelihood of an individual switching in a given round. These results only provide hints and not definite answers. More research on the topic is needed.

\subsection{Treatment Heterogeneity}

Next, we test whether certain people are more likely to succumb to peer effects. We here look at both behavioural types and the social environment in which people live to see if some individuals are more likely to conform than others. There is a growing literature linking cognitive ability and financial literacy to improved financial behaviors and outcomes (see for instance Bertrand and Morse, 2011; Agrawal and Mazumder, 2013). We hypothesize that high cognitive ability individuals should be less prone to peer pressure, while the opposite should be true for low skilled respondents.

Using the cognitive ability question, we create a dummy for those with the 
highest and one dummy for those individuals that have the lowest cognitive ability score compared to their peers within the group to test the effect of relative cognitive ability in a group. To test for the effect of absolute cognitive ability, we generate a dummy for those that scored in the highest $10 \%$ of the distribution. We include these dummies together with an interaction term between the dummy and the leave-out-mean into our regressions above using only the peer treatment. Table 9 shows results. We find that the high cognitive ability (both in relative and in absolute terms) individuals are less likely to succumb to peer effects (column 1 and 3). This effect is weakened when controlling for individual and group characteristics, but the signs remain the same. We, however, do not find any statistically significant results for low cognitive ability people. We also use this method to test whether over-confident and wealthy individuals are more prone to succumb to peer effects. We do not find any significant results.

Another interesting question is whether people who live in closer knit communities are more susceptible to peer effects. The cost of not doing what everyone else in the group is doing may be higher for those that live in communities with stronger social ties. We test whether the peer effect is stronger for those living in smaller villages. For this, we create a dummy that is unity for those respondents that live in villages that are smaller than the median size. Results are shown in Table 9 in columns five and six. We can see that the small village dummy as well as the interaction term are significant. This shows us that those that live in smaller villages are more likely to conform to the group. This indicates that stronger social ties may lead to stronger conforming behavior. We also test whether women are more susceptible to peer effects. It is often argued that women are more social than men and therefore it is possible that they are more likely to be affected by peer effects. However, we find no evidence of this here. 


\section{Robustness}

We start our robustness analysis by checking if the main results hold when we use different dependent variables to see whether individual consumption decisions are still affected by the group, even for those individuals that may lean towards extreme choices. In Table $\mathbf{1 0}$ we use a dummy dependent variable that takes the value of 1 if the respondent chooses the tasty treat in every round. In Table 11, we also use an indicator variable that is 1 if the respondent never chooses the tasty treat - preferring the money from round 1 through round 7. Both tables exhibit the same pattern as Table 6. The group's average consumption choice still influences the individual's consumption choice. Afterwards, we create another set of dependent variables. We want to investigate if results remain robust if the respondent switched before and after 40 THB (see Table $\mathbf{1 2}$ and Table $\mathbf{1 3}$ ). We run all the regressions again and find that the results do not change.

Moreover, we test whether the unfamiliarity with the tasty treat is counteracted by peer effects if instead of the continous variable we use a dummy. The indicator variable is one if the respondent wrongly estimates the price. Our robustness test shows that gaining information from peer effects continues to play a significant role (see Table 14).

In addition, we check whether the distance of the villages to Ubon, the provincial capital city, or the nearest district capital impacts on the demand for tasty treat, since it is conceivable that villages close to urban areas could get the tasty treat more easily, thus affecting the impact of peer effect. We do not find that the distance to the provincial capital or the district capital has any impact on the peer effects and results found in Table $\mathbf{6}$ stay the same. We also control for a number of other village characteristics such as village shocks or their intensity. These also do not seem to make a difference.

We also check whether there are further personal characteristics that may influence the demand for the tasty treat and the strength of the peer effect. We check if those that have particularly high food consumption, low food consumption or high general consumption are more likely to choose the tasty treat in higher rounds. This may either indicate being particularly rich or poor or 
alternatively, those with high food consumption may have a particular high demand for food. We find no effects using any of these consumption variables.

Finally, we test whether our results are driven by one or several settings of the experiment (i.e. morning or afternoon sessions, first or second session, variations in the size of the peer groups). We find that results of Table 6 remain unchanged (for details see Appendix D)

Overall, our results seem robust to a large number of alterations and changes to outcome variables, village charactersitics, individual charactersitics.

\section{Conclusion}

We conduct a lab-in-field experiment which can be linked to a very detailed household survey and find that peer observation leads to conformity. Due to the experimental design and the large number of control variables, we can circumvent the identification problems normally found in studies on peer effects. In the control group, respondents perform the experiment at the same time as their peers but without observing each other. In the treatment group, peers still make individual choices, but observe each other whilst doing it. We find that standard deviations of those groups that observe each other are lower than for those groups that do not observe each other. At the same time, we show that individual choices are influenced by the group choice (measured as the leave-out group mean). Most importantly, we only observe this when the experiment is performed with peer observations. Hence, we provide clear evidence of peer effects and conclude that peer observation leads to conformity.

This finding is in line with other studies on peer effects that look at various outcome variables. Falk and Ichino (2006) who show that the standard deviation of output of subjects in pairs is statistically significantly lower than in the single treatment. Bougheas et al.(2013) also find that there is a positive correlation when peers observe each other, but no change in the average risk taken. The direction of our effects is in line with those of Bandiera et al.(2010), Bursztyn et al. (2014) and De Giorgi et al. (2010) for positive and significant peer effects on individual behavior.

In further analysis we look into the possible mechanism behind this con- 
formity. We study the effect of familiarity with the product and find that peer observation can counteract the effect of a lack of knowledge of a product. There is also evidence that the number of people that switched previously increases the likelihood of an individual switching in the next round. We find no evidence that the characteristics of thoes that switched in the previous round is important.

Finally, we investigate treatment heterogeneities in order to see if the tendency to conform is stronger for some behavioral traits or environments. We find that individuals with high cognitive ability are less likely to choose the tasty treat. We also find evidence that those who live in closer knit communities are more likely to succumb to peer effects.

Despite these findings, many open questions remain, thus further research into peer effects and its effect on consumption choices is needed. So far, there is no consensus on the "best" method to identify peer effects, in part because models and methods must necessarily be case-specific. Furthermore, more research looking into the mechanisms behind peer effects and what leads to conformity is needed. In more detail, a structured experiment may be able to disentangle the effect of information and network externalities and so further explain why we find this conformity when peers observe each other. While our research provides a first insight into this mechanism, additional research should be done into the effect of key individuals within a group - investigating who leads a group and who follows. Another open question is whether peer effects, as found in this experiment, persist beyond the time of observation. 


\section{References}

Agarwal, S. and Mazumder, B. (2013). Cognitive abilities and household financial decision making. American Economic Journal: Applied Economics, $5(1): 193-207$.

Angelucci, M. and De Giorgi, G. (2009). Indirect effects of an aid program: how do cash transfers affect ineligibles consumption? American Economic Review, 99(1):497-516.

Angrist, J. (2013). The perils of peer effects. Labour Economics, 30(1):98-108.

Baecker, A. and Mechtel, M. (2014). Peer effects in cheating on task performance. Unpublished Manuscript.

Bandiera, O., Barankay, I., and Rasul, I. (2010). Social incentives in the workplace. Review of Economic Studies, 77(2):417-458.

Bandiera, O. and Rasul, I. (2006). Social networks and technology adoption in northern Mozambique. Economic Journal, 116(514):869-902.

Banerjee, A. and Mullainathan, S. (2010). The shape of temptation: Implications for the economic lives of the poor. Working Paper No. $25 \%$.

Bernheim, B. D. (1994). A theory of conformity. Journal of Political Economy, 102(5):841.

Bertrand, M. and Morse, A. (2011). Information disclosure, cognitive biases, and payday borrowing. Journal of Finance, 66(6):1865-1893.

Bertrand, M. and Morse, A. (2015). Trickle-down consumption. CEPR Discussion Paper No. 10468.

Bikhchandani, S., Hirshleifer, D., and Welch, I. (1998). Learning from the behavior of others: Conformity, fads, and informational cascades. Journal of Economic Perspectives, 12(3):151-170.

Bolton, G. E. and Ockenfels, A. (2000). ERC: A theory of equity, reciprocity, and competition. American Economic Review, 90(1):166-193.

Boneva, T. (2014). Neighbourhood effects in consumption: Evidence from disaggregated consumption data. Cambridge Working Paper 1328. 
Bougheas, S., Nieboer, J., and Sefton, M. (2013). Risk-taking in social settings: Group and peer effects. Journal of Economic Behavior and Organization, 92(100):273-283.

Bursztyn, L., Ederer, F., Ferman, B., and Yuchtman, N. (2014). Understanding mechanisms underlying peer effects: Evidence from a field experiment on financial decisions. Econometrica, 82(4):1273-1301.

Cai, H., Chen, Y., and Fang, H. (2009). Observational learning: Evidence from a randomized natural field experiment. American Economic Review, $99(3): 864-882$.

Carrell, S. E., Hoekstra, M., and West, J. E. (2011). Is poor fitness contagious? Journal of Public Economics, 95(7-8):657-663.

Chetty, R., Hendren, N., and Katz, L. F. (2015). The effects of exposure to better neighborhoods on children: New evidence from the Moving to Opportunity experiment. American Economic Review, forthcoming.

Chlingingsmith, D. and Sheremeta, R. (2015). Status and the demand for visible goods: Experimental evidence on conspicuous consumption. MPRA Working Paper No. 68202.

Cole, S., Sampson, T., and Zia, B. (2011). Prices or knowledge? What drives demand for financial services in emerging markets? Journal of Finance, 66(6):1933-1967.

Conley, T. G. and Udry, C. R. (2010). Learning about a new technology: Pineapple in Ghana. American Economic Review, 100(1):35-69.

Dohmen, T., Falk, A., Huffman, D., and Sunde, U. (2010). Are risk aversion and impatience related to cognitive ability? American Economic Review, 100(3):1238-1260.

Duflo, E., Dupas, P., and Kremer, M. (2011). Peer effects, teacher incentives, and the impact of tracking: Evidence from a randomized evaluation in Kenya. American Economic Review, 101(5):1739-1774. 
Duflo, E. and Saez, E. (2003). The role of information and social interactions in retirement plan decisions: Evidence from a randomized experiment. Quarterly Journal of Economics, 118(3):815-842.

Falk, A. and Ichino, A. (2006). Clean evidence on peer effects. Journal of Labor Economics, 24(1):39-57.

Fehr, E. and Schmidt, K. (1999). A theory of fairness, competition, and cooperation. Quarterly Journal of Economics, 114(3):817-868.

Foster, A. D. and Rosenzweig, M. R. (1995). Learning by doing and learning from others: Human capital and technical change in agriculture. Journal of Political Economy, 103(6):1176-1209.

Georganas, S., Tonin, M., and Vlassopoulos, M. (2015). Peer pressure and productivity: The role of observing and being observed. Journal of Economic Behavior and Organization, 117(1):223-232.

Giorgi, G. d., Pellizzari, M., and Redaelli, S. (2010). Identification of social interactions through partially overlapping peer groups. American Economic Journal: Applied Economics, 2(2):241-275.

Godlonton, S. and Thornton, R. (2012). Peer effects in learning HIV results. Journal of Development Economics, 97(1):118-129.

Goeree, J. K. and Yariv, L. (2011). An experimental study of collective deliberation. Econometrica, 79(3):893-921.

Gunter, B. and Furnham, A. (1998). Children as Consumers: A Psychological Analysis of the Young People's Market. Routledge, London.

Guryan, J., Kroft, K., and Notowidigdo, M. J. (2009). Peer effects in the workplace: Evidence from random groupings in professional golf tournaments. American Economic Journal: Applied Economics, 1(4):34-68.

Imberman, S. A., Kugler, A. D., and Sacerdote, B. I. (2012). Katrina's children: Evidence on the structure of peer effects from hurricane evacuees. American Economic Review, 102(5):2048-2082. 
Kremer, M. and Levy, D. (2008). Peer effects and alcohol use among college students. Journal of Economic Perspectives, 22(3):189-206.

Kremer, M. and Miguel, E. (2007). The illusion of sustainability. Quarterly Journal of Economics, 122(3):1007-1065.

Kuhn, P., Kooreman, P., Soetevent, A., and Kapteyn, A. (2011). The effects of lottery prizes on winners and their neighbours: Evidence from the dutch postcode lottery. American Economic Review, 101(1):2226-2247.

Mangyo, E. and Park, A. (2011). Relative deprivation and health: Which reference groups matter? Journal of Human Resources, 46(3):459-481.

Manski, C. F. (1993). Identification of endogenous social effects: The reflection problem. Review of Economic Studies, 60(3):531.

Manski, C. F. (2000). Economic analysis of social interactions. Journal of Economic Perspectives, 14(3):115-136.

Mas, A. and Moretti, E. (2009). Peers at work. American Economic Review, 99(1):112-145.

Miguel, E. and Kremer, M. (2004). Worms: Identifying impacts on education and health in the presence of treatment externalities. Econometrica, $72(1): 159-217$.

Moffit, R. (2001). Policy Interventions, Low-Level Equilibria, and Social Interactions. Brookings Institution Press, Washington DC.

Moretti, E. (2011). Social learning and peer effects in consumption: Evidence from movie sales. Review of Economic Studies, 78(1):356-393.

Oster, E. and Thornton, R. (2012). Determinants of technology adoption: Peer effects in menstrual cup take-up. Journal of the European Economic Association, 10(6):1263-1293.

Roth, C. (2014). Conspicuous consumption and peer effects among the poor: Evidence from a field experiment. CSAE Working Paper Series, 29.

Sacerdote, B. (2001). Peer effects with random assignment: Results for Dartmouth roommates. Quarterly Journal of Economics, 116(2):681-704. 
Steinberg, L. and Cauffman, E. (1996). Maturity of judgment in adolescence: Psychosocial factors in adolescent decision making. Law and Human Behavior, 20(3):249-272.

Townsend, R. M. (1994). Risk and insurance in village India. Econometrica, 62(3):539. 
Table 1: Summary Statistics and Tests of Randomisation on Individual and Village Characteristics

\begin{tabular}{lcccc}
\hline \hline \multicolumn{1}{c}{ Variable } & $\begin{array}{c}\text { Non-observing } \\
\text { Groups }\end{array}$ & $\begin{array}{c}\text { Observing } \\
\text { Groups }\end{array}$ & $\begin{array}{c}\text { T-Test } \\
\text { p-value }\end{array}$ & $\begin{array}{c}\text { Wilcoxon Test } \\
\text { p-value }\end{array}$ \\
\hline Panel A: Individual Characteristics & & & & \\
Female & & & & \\
Age & 0.57 & 0.62 & 0.28 & 0.27 \\
Married & 54.17 & 54.11 & 0.96 & 0.89 \\
Years of schooling & 0.80 & 0.85 & 0.13 & 0.13 \\
Household (HH) size & 5.61 & 5.66 & 0.85 & 0.56 \\
Number of children & 4.08 & 4.00 & 0.64 & 0.84 \\
Dependency ratio & 1.22 & 1.01 & 0.02 & 0.06 \\
Farmer & 1.52 & 1.41 & 0.06 & 0.34 \\
Self-employed & 0.69 & 0.69 & 0.98 & 0.98 \\
Public servant & 0.05 & 0.06 & 0.60 & 0.59 \\
Body mass index (BMI) & 0.03 & 0.01 & 0.28 & 0.28 \\
Per capita consumption & 23.03 & 22.93 & 0.77 & 0.75 \\
Total wealth & 2299.92 & 2507.79 & 0.20 & 0.48 \\
Numeracy & 10699.97 & 11095.22 & 0.81 & 0.20 \\
Number of animals & 3.55 & 3.57 & 0.85 & 0.58 \\
Overconfidence & 17.22 & 17.20 & 0.97 & 0.94 \\
Cognitive ability & 0.38 & 0.43 & 0.24 & 0.53 \\
\hline N(Individuals) & -0.03 & 0.04 & 0.97 & 0.95 \\
\hline
\end{tabular}

Panel B: Village Characteristics

$\begin{array}{lcccc}\text { Distance to district capital } & 16.16 & 15.67 & 0.70 & 0.61 \\ \text { Distance to Ubon } & 65.05 & 53.68 & 0.40 & 0.43 \\ \text { No. of village shocks } & 1.47 & 1.50 & 0.91 & 0.65 \\ \text { No. of households } & 163.23 & 171.78 & 0.88 & 0.97 \\ \text { No. of people under } 15 & 136.57 & 156.49 & 0.32 & 0.27 \\ \text { No. of people 15-65 } & 487.22 & 505.90 & 0.97 & 0.74 \\ \text { No. of people over 65 } & 55.89 & 70.70 & 0.26 & 0.49 \\ \text { Participation in social activities } & 66.74 & 71.39 & 0.58 & 0.64 \\ \text { No. of poor households } & 30.00 & 24.00 & 0.36 & 0.18 \\ \text { Having a library } & 0.20 & 0.25 & 0.67 & 0.66\end{array}$

$\mathrm{N}$ (Village) 66

This table reports t-test and Wilcoxon rank-sum tests between treatment and control groups. Household size is the headcount of persons living in the household for at least 180 days. Body mass index is computed weight/height ${ }^{2}$. Numeracy is the number of correct answers out of six math questions (Details can be found in Appendix B). Number of animals is the number of animals that someone can name in 60 seconds. Overconfident is a dummy that is unity if the respondent is overconfident. Cognitive ability is the score generated by performing principal component analysis on the numeracy score and the number of animals named in 60 seconds. Distance to district Capital/Ubon is the average distance of the village to the district and provincial capital in kilometers. Village shock is the number of adverse shocks that affected the village in the last two years. Participation in social acivities is the proportion of households that participated in cultural and social activities in the village. All village characteristics were reported by the village head. 
Table 2: Comparing Means and Standard Deviation for Non-Observing and Observing Groups

\begin{tabular}{|c|c|c|c|c|}
\hline & $\begin{array}{c}\text { Non-observing } \\
\text { Groups }\end{array}$ & $\begin{array}{c}\text { Observing } \\
\text { Groups }\end{array}$ & $\begin{array}{c}\text { T-Test } \\
\text { p-value }\end{array}$ & $\begin{array}{c}\text { Wilcoxon Rank } \\
\text { p-value }\end{array}$ \\
\hline \multicolumn{5}{|l|}{ Panel A: Group Means } \\
\hline Female & 0.58 & 0.63 & 0.30 & 0.24 \\
\hline Age & 54.32 & 54.18 & 0.91 & 0.50 \\
\hline Married & 0.81 & 0.85 & 0.14 & 0.12 \\
\hline Years of schooling & 5.73 & 5.68 & 0.69 & 0.86 \\
\hline Household size & 4.09 & 4.02 & 0.65 & 0.64 \\
\hline Number of children & 1.23 & 1.02 & 0.03 & 0.03 \\
\hline BMI & 23.09 & 23.07 & 0.95 & 0.82 \\
\hline Per capita Consumption & 7.55 & 7.62 & 0.26 & 0.22 \\
\hline Feeling & 2.22 & 2.26 & 0.64 & 0.52 \\
\hline Overconfident & 0.43 & 0.43 & 0.95 & 0.98 \\
\hline Cognitive ability & -0.03 & -0.02 & 0.94 & 0.76 \\
\hline \multicolumn{5}{|c|}{ Panel B: Group Standard Deviations } \\
\hline Female & 0.42 & 0.42 & 0.87 & 0.85 \\
\hline Age & 12.79 & 12.23 & 0.59 & 0.72 \\
\hline Married & 0.31 & 0.25 & 0.18 & 0.22 \\
\hline Years of schooling & 2.24 & 2.22 & 0.95 & 0.95 \\
\hline Household size & 1.51 & 1.52 & 0.94 & 0.42 \\
\hline Number of children & 1.23 & 1.02 & 0.03 & 0.14 \\
\hline BMI & 3.32 & 3.51 & 0.54 & 0.72 \\
\hline Per capita consumption & 0.54 & 0.58 & 0.37 & 0.72 \\
\hline Feeling & 0.79 & 0.77 & 0.71 & 0.72 \\
\hline Overconfidence & 0.46 & 0.42 & 0.32 & 0.15 \\
\hline Cognitive ability & 1.28 & 1.19 & 0.29 & 0.36 \\
\hline $\mathrm{N}$ (Groups) & 126 & & & \\
\hline
\end{tabular}

This table reports t-test and Wilcoxon rank-sum tests between non-observing and observing groups means and standard deviations. Control variables stay the same with the exception of feeling which asks how the respondent feels today before the start of the experiment. It is coded from 1 (very good) to 5 (very bad). 
Table 3: Comparing Outcomes for Non-Observing and Observing Groups

\begin{tabular}{lcccc}
\hline \hline Outcome PayTT & $\begin{array}{c}\text { Non-Observing } \\
\text { Groups }\end{array}$ & $\begin{array}{c}\text { Observing } \\
\text { Groups }\end{array}$ & $\begin{array}{c}\text { T-Test } \\
\text { p-value }\end{array}$ & $\begin{array}{c}\text { Wilcoxon Rank } \\
\text { p-value }\end{array}$ \\
\hline Mean & 2.94 & 2.93 & 0.91 & 0.70 \\
Standard Deviation & 2.26 & 1.70 & 0.00 & 0.00 \\
Group Maximum & 5.74 & 4.93 & 0.01 & 0.04 \\
Group Minimum & 0.68 & 1.21 & 0.03 & 0.11 \\
\hline N (Groups) & 126 & & & \\
\hline
\end{tabular}

This table reports difference of the outcome choice between observing and non-observing groups. We use the payTT which is the last round subjects choose the tasty treat before swichting to money as the outcome variable. Group minimum is the lowest switching point of anyone within the group. Group maximum is the highest switching point within a group. 
Table 4: Group Level Treatment Effect on PayTT

\begin{tabular}{|c|c|c|c|c|}
\hline & $\begin{array}{c}(1) \\
\text { Mean PayTT }\end{array}$ & $\begin{array}{c}(2) \\
\text { Std.Dev. PayTT }\end{array}$ & $\begin{array}{c}(3) \\
\text { Max PayTT }\end{array}$ & $\begin{array}{l}(4) \\
\text { Min PayTT }\end{array}$ \\
\hline Peer Treatment & $\begin{array}{l}0.050 \\
(0.28)\end{array}$ & $\begin{array}{c}-0.487^{* * *} \\
(0.17)\end{array}$ & $\begin{array}{c}-0.111^{*} \\
(0.06)\end{array}$ & $\begin{array}{c}0.600^{* *} \\
(0.26)\end{array}$ \\
\hline Mean Female & $\begin{array}{c}-0.92^{* *} \\
(0.52)\end{array}$ & $\begin{array}{c}-0.632^{* *} \\
(0.42)\end{array}$ & $\begin{array}{c}-0.331^{* * *} \\
(0.12)\end{array}$ & $\begin{array}{l}0.020 \\
(0.70)\end{array}$ \\
\hline Mean Consumption & $\begin{array}{l}0.831 \\
(0.54)\end{array}$ & $\begin{array}{r}-0.030 \\
(0.33)\end{array}$ & $\begin{array}{l}0.091 \\
(0.11)\end{array}$ & $\begin{array}{l}0.921 \\
(0.58)\end{array}$ \\
\hline Mean Age & $\begin{array}{r}-0.013 \\
(0.02)\end{array}$ & $\begin{array}{c}-0.026^{* *} \\
(0.01)\end{array}$ & $\begin{array}{r}-0.003 \\
(0.00)\end{array}$ & $\begin{array}{l}0.015 \\
(0.02)\end{array}$ \\
\hline Mean Cognitive ability & $\begin{array}{r}-0.173 \\
(0.21)\end{array}$ & $\begin{array}{r}-0.139 \\
(0.14)\end{array}$ & $\begin{array}{r}-0.065 \\
(0.05)\end{array}$ & $\begin{array}{r}-0.019 \\
(0.17)\end{array}$ \\
\hline Mean Married & $\begin{array}{l}0.351 \\
(1.15)\end{array}$ & $\begin{array}{r}-0.786 \\
(0.97)\end{array}$ & $\begin{array}{l}-0.167 \\
(0.29)\end{array}$ & $\begin{array}{l}0.512 \\
(1.16)\end{array}$ \\
\hline Mean No. of children & $\begin{array}{l}0.100 \\
(0.31)\end{array}$ & $\begin{array}{l}0.091 \\
(0.20)\end{array}$ & $\begin{array}{l}0.090 \\
(0.07)\end{array}$ & $\begin{array}{l}0.180 \\
(0.36)\end{array}$ \\
\hline Mean Schooling & $\begin{array}{l}0.190 \\
(0.16)\end{array}$ & $\begin{array}{l}0.084 \\
(1.10)\end{array}$ & $\begin{array}{c}0.072^{* *} \\
(0.03)\end{array}$ & $\begin{array}{l}0.152 \\
(0.14)\end{array}$ \\
\hline Mean Household size & $\begin{array}{l}0.050 \\
(0.19)\end{array}$ & $\begin{array}{l}-0.067 \\
(0.11)\end{array}$ & $\begin{array}{l}0.000 \\
(0.04)\end{array}$ & $\begin{array}{l}0.093 \\
(0.16)\end{array}$ \\
\hline Mean Feeling & $\begin{array}{r}-0.161 \\
(0.30)\end{array}$ & $\begin{array}{r}-0.090 \\
(0.20)\end{array}$ & $\begin{array}{r}-0.022 \\
(0.07)\end{array}$ & $\begin{array}{r}-0.122 \\
(0.27)\end{array}$ \\
\hline Mean BMI & $\begin{array}{l}0.001 \\
(0.07)\end{array}$ & $\begin{array}{l}0.015 \\
(0.04)\end{array}$ & $\begin{array}{l}-0.011 \\
(0.02)\end{array}$ & $\begin{array}{l}-0.017 \\
(0.07)\end{array}$ \\
\hline Mean Overconfidence & $\begin{array}{l}0.812 \\
(0.76)\end{array}$ & $\begin{array}{l}0.050 \\
(0.38)\end{array}$ & $\begin{array}{l}0.049 \\
(0.14)\end{array}$ & $\begin{array}{l}0.102 \\
(0.76)\end{array}$ \\
\hline Std.Dev. Female & $\begin{array}{l}0.471 \\
(0.69)\end{array}$ & $\begin{array}{l}0.186 \\
(0.47)\end{array}$ & $\begin{array}{l}0.119 \\
(0.16)\end{array}$ & $\begin{array}{l}0.630 \\
(0.79)\end{array}$ \\
\hline Std.Dev. Consumption & $\begin{array}{r}-0.461 \\
(0.47)\end{array}$ & $\begin{array}{r}-0.431 \\
(0.33)\end{array}$ & $\begin{array}{r}-0.145 \\
(0.10)\end{array}$ & $\begin{array}{l}0.161 \\
(0.46)\end{array}$ \\
\hline Std.Dev. Age & $\begin{array}{l}0.016 \\
(0.02)\end{array}$ & $\begin{array}{l}0.001 \\
(0.00)\end{array}$ & $\begin{array}{l}0.001 \\
(0.00)\end{array}$ & $\begin{array}{l}0.000 \\
(0.02)\end{array}$ \\
\hline Std.Dev. Cognitive ability & $\begin{array}{c}0.838^{* * *} \\
(0.30)\end{array}$ & $\begin{array}{l}0.247 \\
(0.16)\end{array}$ & $\begin{array}{c}0.151^{* * *} \\
(0.05)\end{array}$ & $\begin{array}{l}0.480 \\
(0.31)\end{array}$ \\
\hline Std. Dev. Married & $\begin{array}{l}0.478 \\
(0.89)\end{array}$ & $\begin{array}{l}-0.337 \\
(0.75)\end{array}$ & $\begin{array}{l}0.021 \\
(0.22)\end{array}$ & $\begin{array}{l}0.633 \\
(0.93)\end{array}$ \\
\hline Std.Dev. No. of children & $\begin{array}{c}-0.591^{*} \\
(0.31)\end{array}$ & $\begin{array}{l}-0.221 \\
(0.18)\end{array}$ & $\begin{array}{c}-0.170^{* *} \\
(0.07)\end{array}$ & $\begin{array}{l}-0.211 \\
(0.30)\end{array}$ \\
\hline Std.Dev. Schooling & $\begin{array}{l}-0.191 \\
(0.13)\end{array}$ & $\begin{array}{r}-0.042 \\
(0.08)\end{array}$ & $\begin{array}{c}-0.051^{*} \\
(0.03)\end{array}$ & $\begin{array}{c}-0.233^{*} \\
(0.12)\end{array}$ \\
\hline Std.Dev. Household size & $\begin{array}{l}0.201 \\
(0.21)\end{array}$ & $\begin{array}{l}0.128 \\
(0.12)\end{array}$ & $\begin{array}{l}0.039 \\
(0.04)\end{array}$ & $\begin{array}{l}0.009 \\
(0.22)\end{array}$ \\
\hline Std.Dev. Feeling & $\begin{array}{l}-0.649 \\
(0.48)\end{array}$ & $\begin{array}{l}0.341 \\
(0.33)\end{array}$ & $\begin{array}{r}-0.039 \\
(0.09)\end{array}$ & $\begin{array}{c}-0.846^{*} \\
(0.49)\end{array}$ \\
\hline Std.Dev. Overconfidence & $\begin{array}{l}0.129 \\
(0.77)\end{array}$ & $\begin{array}{l}-0.566 \\
(0.52)\end{array}$ & $\begin{array}{l}0.029 \\
(0.16)\end{array}$ & $\begin{array}{l}0.126 \\
(0.85)\end{array}$ \\
\hline Std.Dev. BMI & $\begin{array}{l}-0.079 \\
(0.09)\end{array}$ & $\begin{array}{l}0.041 \\
(0.06)\end{array}$ & $\begin{array}{l}-0.023 \\
(0.02)\end{array}$ & $\begin{array}{c}-0.169^{* *} \\
(0.09)\end{array}$ \\
\hline Constant & $\begin{array}{l}-3.71 \\
(4.42)\end{array}$ & $\begin{array}{c}4.28 \\
(2.60)\end{array}$ & $\begin{array}{c}1.35 \\
(1.35)\end{array}$ & $\begin{array}{l}-9.70 \\
(4.79)\end{array}$ \\
\hline $\begin{array}{l}\text { R-Squared } \\
\text { Observations }\end{array}$ & $\begin{array}{l}0.21 \\
125\end{array}$ & $\begin{array}{c}0.24 \\
125\end{array}$ & 125 & 125 \\
\hline
\end{tabular}

This table reports regression results with clustered standard errors in parenthesis. ${ }^{* * *},{ }^{* *}$ and $*$ denote significance at the $1 \%, 5 \%$ and $10 \%$ levels, respectively. Peer observation is a dummy that is 1 if the game is played with peers observing each other. Mean (Variables) are the average group composition in the groups. Standard deviation (Variable) is the standard deviation of observed variables in the groups. Column 1 and 2 report OLS estimates. Columns 3 and 4 shoyppoisson results. 
Table 5: Comparing Deciles between Non-Observing and Observing Groups

\begin{tabular}{lcccc}
\hline \hline Decile payTT & $\begin{array}{c}\text { Non-observing } \\
\text { Groups }\end{array}$ & $\begin{array}{c}\text { Observing } \\
\text { Groups }\end{array}$ & $\begin{array}{c}\text { T-Test } \\
\text { p-value }\end{array}$ & $\begin{array}{c}\text { Wilcoxon Rank } \\
\text { p-value }\end{array}$ \\
\hline 1st & 0.68 & 1.21 & 0.03 & 0.11 \\
2nd & 0.92 & 1.41 & 0.06 & 0.33 \\
3rd & 1.55 & 1.90 & 0.27 & 0.44 \\
4th & 2.25 & 2.39 & 0.67 & 0.96 \\
5th & 2.76 & 2.84 & 0.81 & 0.93 \\
6th & 3.29 & 3.32 & 0.94 & 0.92 \\
7th & 4.00 & 3.66 & 0.33 & 0.44 \\
8th & 5.20 & 4.54 & 0.04 & 0.12 \\
9th & 5.74 & 4.93 & 0.01 & 0.46 \\
\hline N(Groups) & 126 & & & \\
\hline
\end{tabular}

This table reports differences in deciles between observing and non-observing groups. We use the payTT which is the last round subjects choose the tasty treat before swichting to money as the outcome variable. 
Table 6: Individual Choice of Tasty Treat and Group Average

\begin{tabular}{|c|c|c|c|c|c|c|c|}
\hline & $\begin{array}{c}\text { Last row } \mathbf{T T} \\
\text { All }\end{array}$ & $\begin{array}{cl} & (2) \\
\text { Last } & \text { row } \mathbf{T T} \\
& \text { All }\end{array}$ & $\begin{array}{c}(3) \\
\text { Last row TT } \\
\text { Peer Treatment }\end{array}$ & $\begin{array}{c}(4) \\
\text { Last row TT } \\
\text { Peer Treatment }\end{array}$ & $\begin{array}{cl} & (5) \\
\text { Last row TT } & \text { Tingle Treatment }\end{array}$ & $\begin{array}{c}\text { (6) } \\
\text { Last row TT } \\
\text { Single Treatment }\end{array}$ & $\begin{array}{c}\text { Last row } \mathbf{T T} \\
\text { All }\end{array}$ \\
\hline Group Mean without Self & $\begin{array}{c}0.444^{* * *} \\
(0.08)\end{array}$ & $\begin{array}{c}0.403^{* * *} \\
(0.10)\end{array}$ & $\begin{array}{c}0.670^{* * *} \\
(0.07)\end{array}$ & $\begin{array}{c}0.627^{* * *} \\
(0.13)\end{array}$ & $\begin{array}{l}0.008 \\
(0.18)\end{array}$ & $\begin{array}{l}0.031 \\
(0.20)\end{array}$ & $\begin{array}{l}0.304^{*} \\
(0.12)\end{array}$ \\
\hline Peer*Group Mean Without Self & & & & & & & $\begin{array}{l}0.162^{*} \\
(0.08)\end{array}$ \\
\hline $\begin{array}{l}\text { Group Average Characteristics } \\
\text { (excluding the individual) }\end{array}$ & No & Yes & No & Yes & No & Yes & Yes \\
\hline Individual Characteristics & No & Yes & No & Yes & No & Yes & Yes \\
\hline Constant & $\begin{array}{c}1.59^{* * *} \\
(0.25)\end{array}$ & $\begin{array}{c}2.88 \\
(2.25)\end{array}$ & $\begin{array}{c}0.91^{* * *} \\
(0.21)\end{array}$ & $\begin{array}{c}2.47 \\
(3.79)\end{array}$ & $\begin{array}{c}2.84^{* * *} \\
(0.53)\end{array}$ & $\begin{array}{c}7.05 \\
(4.40)\end{array}$ & $\begin{array}{c}3.41 \\
(2.34)\end{array}$ \\
\hline R-Squared & 0.08 & 0.12 & 0.25 & 0.30 & 0.00 & 0.12 & 0.14 \\
\hline Observations & 537 & 442 & 256 & 203 & 278 & 236 & 439 \\
\hline
\end{tabular}

This table reports OLS regression results with clustered standard errors in parenthesis. ${ }^{* * *}, * *$ and $*$ denote significance at the $1 \%, 5 \%$ and $10 \%$ levels, respectively. Group Average controls include all the group average excluding the individual controls from Table 2. 
Table 7: Unfamiliarity with the Tasty Treat

\begin{tabular}{|c|c|c|c|c|c|c|}
\hline & $\begin{array}{ll} & (1) \\
\text { Last } & \text { row } \mathbf{T T} \\
& \text { All }\end{array}$ & $\begin{array}{cl} & (2) \\
\text { Last row } & \mathbf{T T} \\
& \text { All }\end{array}$ & $\begin{array}{c}(3) \\
\text { Last row TT } \\
\text { Peer Treatment }\end{array}$ & $\begin{array}{c}(4) \\
\text { Last row TT } \\
\text { Peer Treatment }\end{array}$ & $\begin{array}{c}\text { (5) } \\
\text { Last row TT } \\
\text { Single Treatment }\end{array}$ & $\begin{array}{c}\text { (6) } \\
\text { Last row TT } \\
\text { Single Treatment }\end{array}$ \\
\hline Group Mean without Self & $\begin{array}{c}0.371^{* * *} \\
(0.10)\end{array}$ & $\begin{array}{c}0.301^{* *} \\
(0.12)\end{array}$ & $\begin{array}{c}0.647^{* * *} \\
(0.08)\end{array}$ & $\begin{array}{c}0.611^{* * *} \\
(0.14)\end{array}$ & $\begin{array}{l}-0.224 \\
(0.21)\end{array}$ & $\begin{array}{l}-0.252 \\
(0.20)\end{array}$ \\
\hline Unfamiliarity & $\begin{array}{r}-0.039 \\
(0.03)\end{array}$ & $\begin{array}{r}-0.552 \\
(0.03)\end{array}$ & $\begin{array}{r}-0.007 \\
(0.05)\end{array}$ & $\begin{array}{l}-0.001 \\
(0.807)\end{array}$ & $\begin{array}{c}-0.101^{* *} \\
(0.05)\end{array}$ & $\begin{array}{c}-0.131^{* * *} \\
(0.04)\end{array}$ \\
\hline Group Mean without Self*Unfamiliarity & $\begin{array}{l}0.008 \\
(0.01)\end{array}$ & $\begin{array}{l}0.008 \\
(0.01)\end{array}$ & $\begin{array}{l}0.003 \\
(0.01)\end{array}$ & $\begin{array}{l}0.001 \\
(0.02)\end{array}$ & $\begin{array}{l}0.179^{*} \\
(0.01)\end{array}$ & $\begin{array}{c}0.030^{* *} \\
(0.01)\end{array}$ \\
\hline $\begin{array}{l}\text { Group Average Characteristics } \\
\text { (excluding the individual) }\end{array}$ & No & Yes & No & Yes & No & Yes \\
\hline Individual Characteristics & No & Yes & No & Yes & No & Yes \\
\hline Constant & $\begin{array}{l}1.91 \\
(0.36)\end{array}$ & $\begin{array}{c}3.42 \\
(2.34)\end{array}$ & $\begin{array}{c}.96 \\
(0.32)\end{array}$ & $\begin{array}{l}1.87 \\
(3.76)\end{array}$ & $\begin{array}{c}3.79 \\
(0.73)\end{array}$ & $\begin{array}{l}7.30 \\
(3.87)\end{array}$ \\
\hline R-Squared & 0.09 & 0.13 & 0.25 & 0.30 & 0.01 & 0.14 \\
\hline Observations & 537 & 436 & 256 & 197 & 278 & 235 \\
\hline
\end{tabular}

This table reports OLS regression results with clustered standard errors in parenthesis. ${ }^{* * *}, * *$ and $*$ denote significance at the $1 \%, 5 \%$ and $10 \%$ levels, respectively. Group Mean controls include all the controls from Table 2. Unfamiliarity is calculated: price minus estimate. Negative values are multiplied by -1 . 
Table 8: Likelihood of switching on those that switched in previous round

\begin{tabular}{|c|c|c|c|c|c|c|}
\hline & $\begin{array}{c}(1) \\
\text { Switch round } 2 \\
\text { Peer Treatment }\end{array}$ & $\begin{array}{c}\text { (2) } \\
\text { Switch round } \mathbf{2} \\
\text { Single Treatment }\end{array}$ & $\begin{array}{c}(3) \\
\text { Switch round } \mathbf{3} \\
\text { Peer Treatment }\end{array}$ & $\begin{array}{c}\text { (4) } \\
\text { Switch round } \mathbf{3} \\
\text { Single Treatment }\end{array}$ & $\begin{array}{c}(5) \\
\text { Switch round } 4 \\
\text { Peer Treatment }\end{array}$ & $\begin{array}{l}\text { (6) } \\
\text { Switch round } 4 \\
\text { Single Treatment }\end{array}$ \\
\hline Proportion of group switching in previous round & $\begin{array}{c}1.65^{* *} \\
(0.71)\end{array}$ & $\begin{array}{l}-0.24 \\
(0.79)\end{array}$ & $\begin{array}{c}3.29^{* *} \\
(1.66)\end{array}$ & $\begin{array}{c}0.92 \\
(0.69)\end{array}$ & $\begin{array}{c}0.14 \\
(0.75)\end{array}$ & $\begin{array}{c}0.15 \\
(0.63)\end{array}$ \\
\hline Group Average Controls & Yes & Yes & Yes & Yes & Yes & Yes \\
\hline Individual Characteristics & Yes & Yes & Yes & Yes & Yes & Yes \\
\hline Constant & $\begin{array}{l}-2.80 \\
(3.87)\end{array}$ & $\begin{array}{l}-2.60 \\
(3.76)\end{array}$ & $\begin{array}{l}-0.62 \\
(4.32)\end{array}$ & $\begin{array}{l}-8.46 \\
(8.42)\end{array}$ & $\begin{array}{c}-6.9 \\
(5.13)\end{array}$ & $\begin{array}{c}0.16 \\
(5.00)\end{array}$ \\
\hline R-Squared & 0.26 & 0.19 & 0.50 & 0.21 & 0.30 & 0.23 \\
\hline Observations & 146 & 178 & 117 & 155 & 105 & 131 \\
\hline
\end{tabular}

This table reports Probit regression results with standard errors in parenthesis $* * *, * *$ and $*$ denote significance at the $1 \%, 5 \%$ and $10 \%$ levels, respectively. The dependent variable is unity if an individual switches from money to the tasty treat in that row. Only individuals that had not switched before are included in the regression. The right hand side variables is the proportion of the groups that had switched in any previous round. 
Table 9: Treatment Heterogeneity: High Cognitive Ability and Living in Small Villages

\begin{tabular}{|c|c|c|c|c|c|c|}
\hline & $\begin{array}{c}(1) \\
\text { PayTT } \\
\text { Peer }\end{array}$ & $\begin{array}{c}(2) \\
\text { PayTT } \\
\text { Peer Treatment }\end{array}$ & $\begin{array}{c}(3) \\
\text { PayTT } \\
\text { Peer Treatment }\end{array}$ & $\begin{array}{c}(4) \\
\text { PayTT } \\
\text { Peer Treatment }\end{array}$ & $\begin{array}{c}(5) \\
\text { PayTT } \\
\text { Peer Treatment }\end{array}$ & $\begin{array}{c}6) \\
\text { PayTT } \\
\text { Peer Treatment }\end{array}$ \\
\hline Group Mean without Self & $\begin{array}{c}0.70^{* * *} \\
(0.07)\end{array}$ & $\begin{array}{c}0.64^{* * *} \\
(0.13)\end{array}$ & $\begin{array}{c}0.78^{* * *} \\
(0.08)\end{array}$ & $\begin{array}{c}0.69^{* * *} \\
(0.13)\end{array}$ & $\begin{array}{c}0.50^{* * *} \\
(0.14)\end{array}$ & $\begin{array}{c}0.34 \\
(0.25)\end{array}$ \\
\hline Cognitive Ability in Top $10 \%$ & $\begin{array}{c}0.76 \\
(0.58)\end{array}$ & $\begin{array}{c}0.39 \\
(0.70)\end{array}$ & & & & \\
\hline Group Mean without Self*Cognitive Ability in Top $10 \%$ & $\begin{array}{l}-0.26^{*} \\
(0.14)\end{array}$ & $\begin{array}{l}-0.05 \\
(0.22)\end{array}$ & & & & \\
\hline Highest Cognitive Ability in Group & & & $\begin{array}{l}(0.38) \\
(0.58)\end{array}$ & $\begin{array}{c}(-0.25) \\
(0.78)\end{array}$ & & \\
\hline Groups Mean without Self*Highest Cog. Ability in Group & & & $\begin{array}{c}-0.38^{* *} \\
(0.16)\end{array}$ & $\begin{array}{c}(-0.19) \\
(0.19)\end{array}$ & & \\
\hline Living in small Village & & & & & $\begin{array}{c}-1.04^{* *} \\
(0.49)\end{array}$ & $\begin{array}{c}-1.79^{* *} \\
(0.87)\end{array}$ \\
\hline Group Mean Without Self*Living in small Village & & & & & $\begin{array}{l}0.26^{*} \\
(0.15)\end{array}$ & $\begin{array}{l}0.49^{*} \\
(0.27)\end{array}$ \\
\hline Group Average Controls & No & Yes & No & Yes & No & Yes \\
\hline Individual Characteristics & No & Yes & No & Yes & No & Yes \\
\hline R-Squared & 0.26 & 0.30 & 0.29 & 0.32 & 0.27 & 0.33 \\
\hline Observations & 256 & 197 & 256 & 197 & 256 & 197 \\
\hline
\end{tabular}

This table reports regression results with standard errors in parenthesis. $* * *, * *$ and $*$ denote significance at the $1 \%, 5 \%$ and $10 \%$ levels, respectively. The dependent variable is the last round someone chooses the tasty treat. Cognitive Ability in top $10 \%$ is a dummy that is one if the respondent scored in the top $10 \%$ on the cognitive ability tests. Highest Cognitive Ability in groups is a dummy that is one for the respondent with the highest cognitive ability score in the group. Small village is a dummy that is one if the respondent lives in a village that is below the median village size. Peer* indicates an interaction term between group means without self and the respective dummy. 
Table 10: Choosing the Tasty Treat in every round and Group Average without Self

\begin{tabular}{|c|c|c|c|c|c|c|c|}
\hline & $\begin{array}{c}1) \\
\text { Always TT } \\
\text { All }\end{array}$ & $\begin{array}{c}(2) \\
\text { Always TT } \\
\text { All }\end{array}$ & $\begin{array}{c}(3) \\
\text { Always TT } \\
\text { Peer Treatment }\end{array}$ & $\begin{array}{c}(4) \\
\text { Always TT } \\
\text { Peer Treatment } \\
\end{array}$ & $\begin{array}{c}5) \\
\text { Always TT } \\
\text { Single Treatment }\end{array}$ & $\begin{array}{c}6) \\
\text { Always TT } \\
\text { Single Treatment }\end{array}$ & $\begin{array}{c}(7) \\
\text { Always } \mathbf{T T} \\
\text { All }\end{array}$ \\
\hline Group Mean without Self & $\begin{array}{c}0.156^{* *} \\
(0.05)\end{array}$ & $\begin{array}{c}0.186^{* *} \\
(0.06)\end{array}$ & $\begin{array}{c}0.261^{* * *} \\
(0.06)\end{array}$ & $\begin{array}{c}0.468^{* * *} \\
(0.12)\end{array}$ & $\begin{array}{r}-0.006 \\
(0.09)\end{array}$ & $\begin{array}{l}0.072 \\
(0.09)\end{array}$ & $\begin{array}{c}0.141^{*} \\
(0.07)\end{array}$ \\
\hline Peer*Group Mean Without Self & & & & & & & $\begin{array}{l}0.077 \\
(0.05)\end{array}$ \\
\hline $\begin{array}{l}\text { Group Average Characteristics } \\
\text { (excluding the individual) }\end{array}$ & No & Yes & No & Yes & No & Yes & Yes \\
\hline Individual Characteristics & No & Yes & No & Yes & No & Yes & Yes \\
\hline Constant & $\begin{array}{c}-1.71^{* * *} \\
(0.17)\end{array}$ & $\begin{array}{c}0.66 \\
(1.71)\end{array}$ & $\begin{array}{c}-2.09^{* * *} \\
(0.25)\end{array}$ & $\begin{array}{c}5.95 \\
(3.45)\end{array}$ & $\begin{array}{c}-1.24^{* * *} \\
(0.26)\end{array}$ & $\begin{array}{c}0.29 \\
(2.73)\end{array}$ & $\begin{array}{c}0.92 \\
(1.77)\end{array}$ \\
\hline Pseudo R-Squared & 0.03 & 0.13 & 0.11 & 0.36 & 0.00 & 0.17 & 0.13 \\
\hline Observations & 537 & 442 & 256 & 203 & 278 & 236 & 439 \\
\hline
\end{tabular}

This table reports Probit regression results with clustered standard errors in parenthesis. ***, ** and * denote significance at the $1 \%, 5 \%$ and $10 \%$ levels, respectively.The outcome variable is one if the respondent always chooses the tasty treat. Group Average controls include all the controls from Table 2 but excluding the individual. 
Table 11: Never Choosing the Tasty Treat and Group average without Self

\begin{tabular}{|c|c|c|c|c|c|c|c|}
\hline & $\begin{array}{c}(1) \\
\text { Never TT } \\
\text { All }\end{array}$ & $\begin{array}{c}(2) \\
\text { Never TT } \\
\text { All }\end{array}$ & $\begin{array}{c}(3) \\
\text { Never TT } \\
\text { Peer Treatment }\end{array}$ & $\begin{array}{c}(4) \\
\text { Never TT } \\
\text { Peer Treatment }\end{array}$ & $\begin{array}{c}(5) \\
\text { Never TT } \\
\text { Single Treatment }\end{array}$ & $\begin{array}{c}(6) \\
\text { Never TT } \\
\text { Single Treatment }\end{array}$ & $\begin{array}{c}(7) \\
\text { Never TT } \\
\text { All }\end{array}$ \\
\hline Group Mean without Self & $\begin{array}{c}-0.147^{* *} \\
(0.05)\end{array}$ & $\begin{array}{c}-0.153^{* *} \\
(0.06)\end{array}$ & $\begin{array}{c}-0.247^{* * *} \\
(0.07)\end{array}$ & $\begin{array}{c}-0.276^{* *} \\
(0.09)\end{array}$ & $\begin{array}{l}0.023 \\
(0.08)\end{array}$ & $\begin{array}{c}-0.006 \\
(0.09)\end{array}$ & $\begin{array}{l}-0.115 \\
(0.07)\end{array}$ \\
\hline Peer*Group Mean Without Self & & & & & & & $\begin{array}{l}-0.078 \\
(0.05)\end{array}$ \\
\hline $\begin{array}{l}\text { Group Average Characteristics } \\
\text { (excluding the individual) }\end{array}$ & No & Yes & No & Yes & No & Yes & Yes \\
\hline Individual Characteristics & No & Yes & No & Yes & No & Yes & Yes \\
\hline Constant & $\begin{array}{l}-0.28 \\
(0.15)\end{array}$ & $\begin{array}{l}-0.32 \\
(1.32)\end{array}$ & $\begin{array}{l}-0.02 \\
(0.20)\end{array}$ & $\begin{array}{c}0.87 \\
(1.78)\end{array}$ & $\begin{array}{c}-0.79^{* * *} \\
(0.24)\end{array}$ & $\begin{array}{l}-2.53 \\
(2.81)\end{array}$ & $\begin{array}{l}-0.36 \\
(1.32)\end{array}$ \\
\hline Pseudo R-Squared & 0.02 & 0.07 & 0.08 & 0.20 & 0.00 & 0.11 & 0.07 \\
\hline Observations & 537 & 442 & 256 & 203 & 278 & 236 & 439 \\
\hline
\end{tabular}

This table reports Probit regression results with clustered standard errors in parenthesis. ***, ** and * denote significance at the $1 \%, 5 \%$ and $10 \%$ levels, respectively. The outcome variable is one if the respondent never chooses the tasty treat. Group Average controls include all the controls from Table 2 but excluding the individual. 
Table 12: Choosing the Tasty Treat below 40 THB and Group Average without Self

\begin{tabular}{|c|c|c|c|c|c|c|c|}
\hline & $\begin{array}{c}(1) \\
\text { Underprice } \\
\text { All }\end{array}$ & $\begin{array}{c}(2) \\
\text { Underprice } \\
\text { All }\end{array}$ & $\begin{array}{c}(3) \\
\text { Underprice } \\
\text { Peer Treatment }\end{array}$ & $\begin{array}{c}(4) \\
\text { Underprice } \\
\text { Peer Treatment }\end{array}$ & $\begin{array}{c}(5) \\
\text { Underprice } \\
\text { Single Treatment }\end{array}$ & $\begin{array}{c}(6) \\
\text { Underprice } \\
\text { Single Treatment }\end{array}$ & $\begin{array}{c}(7) \\
\text { Underprice } \\
\text { All }\end{array}$ \\
\hline Group Mean without Self & $\begin{array}{c}-0.222^{* * *} \\
(0.04)\end{array}$ & $\begin{array}{c}-0.212^{* * *} \\
(0.05)\end{array}$ & $\begin{array}{c}-0.351^{* * *} \\
(0.05)\end{array}$ & $\begin{array}{c}-0.332^{* * *} \\
(0.07)\end{array}$ & $\begin{array}{r}-0.006 \\
(0.08)\end{array}$ & $\begin{array}{r}-0.007 \\
(0.09)\end{array}$ & $\begin{array}{c}-0.149^{* * *} \\
(0.05)\end{array}$ \\
\hline Peer*Group Mean Without Self & & & & & & & $\begin{array}{c}-0.104^{* *} \\
(0.04)\end{array}$ \\
\hline $\begin{array}{l}\text { Group Average Characteristics } \\
\text { (excluding the individual) }\end{array}$ & No & Yes & No & Yes & No & Yes & Yes \\
\hline Individual Characteristics & No & Yes & No & Yes & No & Yes & Yes \\
\hline Constant & $\begin{array}{c}0.85^{* * *} \\
(0.13)\end{array}$ & $\begin{array}{c}0.37 \\
(1.47)\end{array}$ & $\begin{array}{c}1.20^{* * *} \\
(0.16)\end{array}$ & $\begin{array}{c}0.29 \\
(2.61)\end{array}$ & $\begin{array}{l}-1.20 \\
(0.25)\end{array}$ & $\begin{array}{l}-2.53 \\
(1.81)\end{array}$ & $\begin{array}{c}0.12 \\
(1.38)\end{array}$ \\
\hline Pseudo R-Squared & 0.05 & 0.09 & 0.15 & 0.23 & 0.00 & 0.10 & 0.07 \\
\hline Observations & 554 & 456 & 246 & 209 & 287 & 244 & 453 \\
\hline
\end{tabular}

This table reports Probit regression results with clustered standard errors in parenthesis. ${ }^{* * *},{ }^{* *}$ and ${ }^{*}$ denote significance at the $1 \%, 5 \%$ and $10 \%$ levels, respectively. Group Average controls include all the controls from Table 2 but excluding the individual. Underprice signifies a dummy that is one if the switching row is below $40 \mathrm{THB}$ 
Table 13: Choosing the Tasty Treat above 40 THB and Group Average without Self

\begin{tabular}{|c|c|c|c|c|c|c|c|}
\hline & $\begin{array}{c}(1) \\
\text { Overprice } \\
\text { All }\end{array}$ & $\begin{array}{c}(2) \\
\text { Overprice } \\
\text { All }\end{array}$ & $\begin{array}{c}(3) \\
\text { Overprice } \\
\text { Peer Treatment }\end{array}$ & $\begin{array}{c}(4) \\
\text { Overprice } \\
\text { Peer Treatment }\end{array}$ & $\begin{array}{c}(5) \\
\text { Overprice } \\
\text { Single Treatment }\end{array}$ & $\begin{array}{c}(6) \\
\text { Overprice } \\
\text { Single Treatment }\end{array}$ & $\begin{array}{c}(7) \\
\text { Overprice } \\
\text { All }\end{array}$ \\
\hline Group Mean without Self & $\begin{array}{c}0.156^{* * *} \\
(0.04)\end{array}$ & $\begin{array}{c}0.164^{* * *} \\
(0.05)\end{array}$ & $\begin{array}{c}0.278^{* * *} \\
(0.05)\end{array}$ & $\begin{array}{c}0.298^{* * *} \\
(0.07)\end{array}$ & $\begin{array}{l}-0.052 \\
(0.09)\end{array}$ & $\begin{array}{l}-0.042 \\
(0.09)\end{array}$ & $\begin{array}{c}-0.091^{*} \\
(0.05)\end{array}$ \\
\hline Peer*Group Mean Without Self & & & & & & & $\begin{array}{c}0.077^{* * *} \\
(0.04)\end{array}$ \\
\hline $\begin{array}{l}\text { Group Average Characteristics } \\
\text { (exluding the individual) }\end{array}$ & No & Yes & No & Yes & No & Yes & Yes \\
\hline Individual Characteristics & No & Yes & No & Yes & No & Yes & Yes \\
\hline Constant & $\begin{array}{c}-1.08^{* * *} \\
(0.14)\end{array}$ & $\begin{array}{l}-0.45 \\
(1.51)\end{array}$ & $\begin{array}{c}-1.45^{* * *} \\
(0.17)\end{array}$ & $\begin{array}{l}-0.17 \\
(2.17)\end{array}$ & $\begin{array}{l}-0.51^{*} \\
(0.26)\end{array}$ & $\begin{array}{c}0.18 \\
(2.59)\end{array}$ & $\begin{array}{l}-0.32 \\
(1.45)\end{array}$ \\
\hline Pseudo R-Squared & 0.02 & 0.07 & 0.11 & 0.21 & 0.00 & 0.07 & 0.06 \\
\hline Observations & 554 & 456 & 264 & 209 & 287 & 244 & 453 \\
\hline
\end{tabular}

This table reports Probit regression results with clustered standard errors in parenthesis. ${ }^{* * *}, * *$ and $*$ denote significance at the $1 \%, 5 \%$ and $10 \%$ levels, respectively. Group Average controls include all the controls from Table 3 but excluding the individual. Overprice is a dummy that is one if the switching row is above 40 THB. 
Table 14: Familiarity with the Tasty Treat

\begin{tabular}{|c|c|c|c|c|c|c|}
\hline & 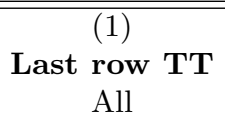 & $\begin{array}{c}\text { Last row } \mathbf{T T} \\
\text { All }\end{array}$ & $\begin{array}{c}(3) \\
\text { Last row TT } \\
\text { Peer Treatment }\end{array}$ & $\begin{array}{c}(4) \\
\text { Last row TT } \\
\text { Peer Treatment }\end{array}$ & $\begin{array}{c}(5) \\
\text { Last row TT } \\
\text { Single Treatment }\end{array}$ & $\begin{array}{c}(6) \\
\text { Last row TT } \\
\text { Single Treatment }\end{array}$ \\
\hline Group Mean without Self & $\begin{array}{c}0.442^{* *} \\
(0.15)\end{array}$ & $\begin{array}{l}0.331^{*} \\
(0.17)\end{array}$ & $\begin{array}{c}0.827^{* * *} \\
(0.13)\end{array}$ & $\begin{array}{c}0.841^{* * *} \\
(0.17)\end{array}$ & $\begin{array}{r}-0.384^{*} \\
(0.22)\end{array}$ & $\begin{array}{r}-0.482^{*} \\
(0.26)\end{array}$ \\
\hline Unfamiliarity (dummy) & $\begin{array}{l}-0.125 \\
(0.58)\end{array}$ & $\begin{array}{l}-0.452 \\
(0.66)\end{array}$ & $\begin{array}{l}0.917 \\
(0.58)\end{array}$ & $\begin{array}{c}1.05 \\
(0.86)\end{array}$ & $\begin{array}{c}-2.101^{* * *} \\
(0.74)\end{array}$ & $\begin{array}{c}-2.591^{* * *} \\
(0.92)\end{array}$ \\
\hline Group Mean without Self*Unfamiliarity & $\begin{array}{l}-0.008 \\
(0.16)\end{array}$ & $\begin{array}{l}0.081 \\
(0.18)\end{array}$ & $\begin{array}{l}-0.203 \\
(0.18)\end{array}$ & $\begin{array}{l}-0.164 \\
(0.25)\end{array}$ & $\begin{array}{c}0.479^{* *} \\
(0.22)\end{array}$ & $\begin{array}{l}0.55^{* *} \\
(0.29)\end{array}$ \\
\hline $\begin{array}{l}\text { Group Average Characteristics } \\
\text { (exluding the individual) }\end{array}$ & No & Yes & No & Yes & No & Yes \\
\hline Individual Characteristics & No & Yes & No & Yes & No & Yes \\
\hline Constant & $\begin{array}{c}1.7 \\
(0.34)\end{array}$ & $\begin{array}{c}3.35 \\
(2.39)\end{array}$ & $\begin{array}{c}0.66 \\
(0.33)\end{array}$ & $\begin{array}{l}1.59 \\
(3.96)\end{array}$ & $\begin{array}{c}3.37 \\
(0.64)\end{array}$ & $\begin{array}{c}7.37 \\
(4.00)\end{array}$ \\
\hline R-Squared & 0.08 & 0.13 & 0.26 & 0.31 & 0.02 & 0.15 \\
\hline Observations & 537 & 442 & 256 & 203 & 278 & 235 \\
\hline
\end{tabular}

This table reports OLS regression results with clustered standard errors in parenthesis. ${ }^{* * *},{ }^{* *}$ and $*$ denote significance at the $1 \%, 5 \%$ and $10 \%$ levels respectively. Group Mean controls include all the controls from Table 2. Unfamiliarity is an indicator variable that is 1 if the individual wrongly estimates the price prior to the experiment. 


\section{A Appendix Sample Design and Experimental Instructions}

\section{A.1 Sample Design}

The household survey contains detailed information on many aspects of each households' living standards including: household demographics, recurrent and durable expenditures, credit and savings, landholdings, agriculture, employment, health, as well as education. It also includes information concerning village characteristics such as the number of village institutions or infrastructure (i.e. irrigation system, access to electricity, nurseries etc.), in - and outward village migration, inhabitants, but also the number of shocks occurring in a village. This data provides a representative sample of rural households in the Northeastern part of Thailand.

The sampling procedure of rural households for the peer experiment conducted in Ubon Ratchathani follows a three-stage stratified sampling procedure. It is important to know that we exclude the urban area around the provincial capital city and confine the sample to the remaining rural areas. In the first stage sub-districts within the province were chosen with probability proportional to size and implicit stratification by population density. In the second stage, from each sampled sub-district, two villages were sampled randomly with probability of selection proportional to size. In the last step, in each of those villages a systematic random sample of ten households was drawn to be interviewed from the household lists of the rural census ordered by household size. To conclude, villages as well as respondents were randomly sampled for our peer experiment. 


\section{A.2 Experimental Instructions}

The experiment was carried out by local enumerators with one of the coauthors being present at all times. Instructions were translated from English into Thai and back, and were cross-checked by a native speaking Thai economics professor to avoid semantic difficulties. Instructions were kept as simple as possible. The interviewers were trained in sessions that lasted a total of five days. During these five days, a pilot study was conducted in three villages.

The experiment was conducted by visiting two villages per day; one in the morning and one in the afternoon. For neighboring villages experiments were usually carried out simultaneously. The distance between villages was on average $18 \mathrm{~km}$ and respondents had to stay at the experimental site until the completion of the survey. There were two experimental sessions conducted in each village, with up to five respondents in one session at the same time. All experimental sessions took place in the village hall.

Instructions: We would now like to play a game with you in which you have to choose between some tasty goods or money. At the end of the game you can keep either the tasty goods or the money. We will ask you to choose between the two options 7 times. Each time we ask you, we increase the amount of money. The amount of tasty goods will always be the same. The enumerator will write down your choice each time we ask you. After the game, we will draw a number from a bag. This determines which of the two options you get. The tasty good will be given to you straight after the game. The money, however, will be given to you at the end of the whole survey. You will only receive one option. Either money or tasty good. 
Example: No.3 is drawn from the bag. For the third decision you chose the tasty treat, so you will get the tasty treat immediately. Enumerator put tasty good on the table.

Enumerator will present the tasty good and ask the following question. Please estimate the price of the tasty treat in the market.

Price of tasty treat (THB)

Enumerator tells respondent that the price of the tasty present is THB 40 and put up the sign that shows the price.

\section{Please choose!}

\begin{tabular}{|l|l||l||l|}
\hline Row & Tasty Good & Tick Box & Money \\
\hline 1 & Tasty Good & & 10 THB \\
\hline 2 & Tasty Good & & 20 THB \\
\hline 3 & Tasty Good & & 30 THB \\
\hline 4 & Tasty Good & & 40 THB \\
\hline 5 & Tasty Good & & 50 THB \\
\hline 6 & Tasty Good & & 60 THB \\
\hline 7 & Tasty Good & & 70 THB \\
\hline
\end{tabular}

What is the maximum you would to pay for the tasty good? (THB)

Now chance will decide! Please draw a number. Number drawn: (THB) 
Figure A.1: Control

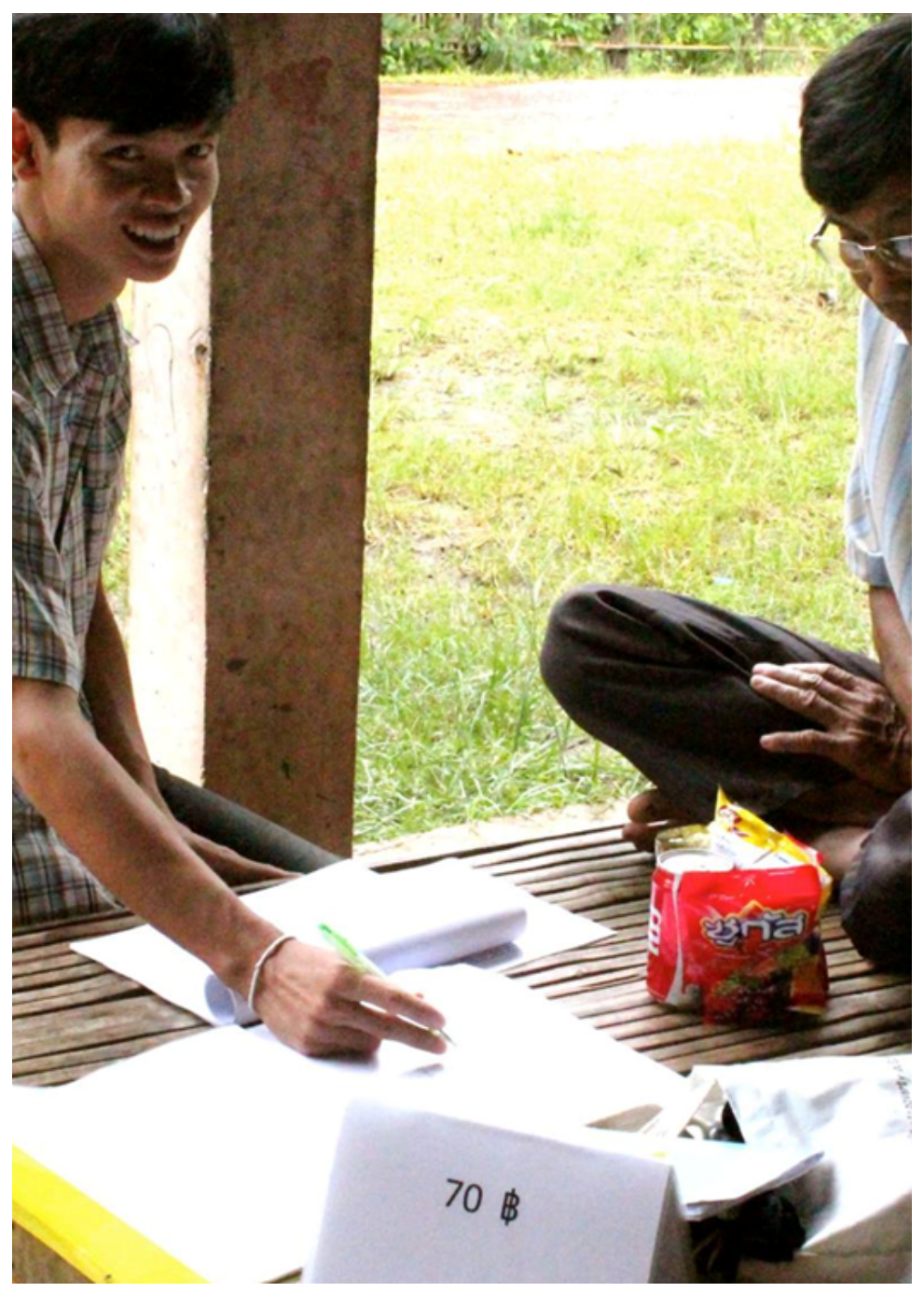


Figure A.2: Treatment

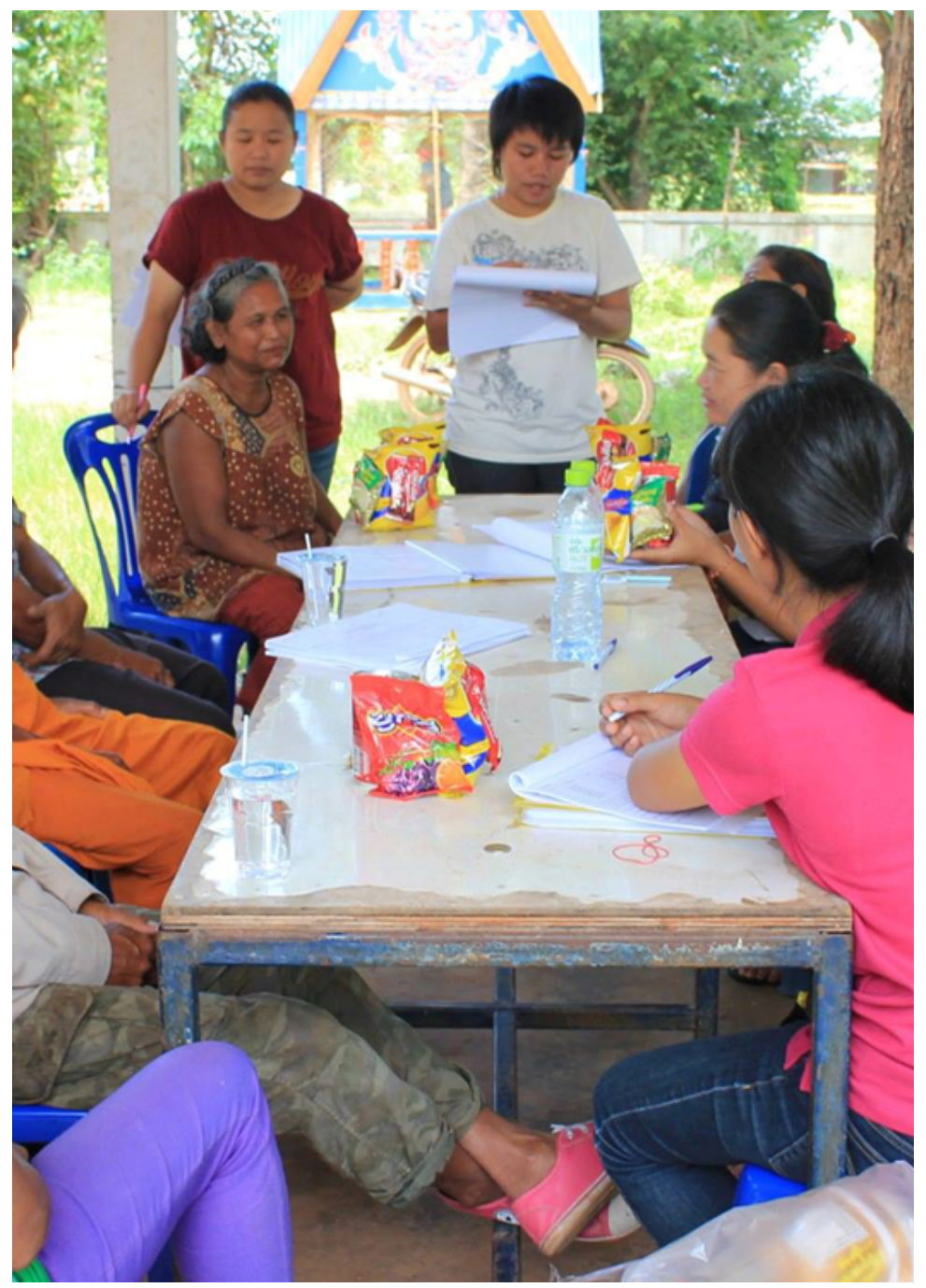




\section{B Appendix \\ Measurement of Numeracy and Overconfidence}

We collected a number of math based questions. In total there were six questions, the first four are based on the hardest four out of eight math questions in Cole et al. (2011), the last two questions are based on question used in the Survey of Health, Ageing and Retirement in Europe (SHARE). In addition, we included a question that asks respondents to name as many animals as they can in 60 seconds. This is a measure of word fluency and has the advantage that it is related to more innate forms of intelligence and especially measures processing speed. This test for word fluency has also been used in a number of other studies as part of cognitive ability measures such as Dohmen et al. (2010).

Finally, we ask respondents to judge how many of these questions they answered correctly to measure overconfidence. Overconfidence results in unrealistically positive self-evaluations. In other words, people are unrealistically optimistic and overestimate personal success probabilities. Our primary measure of confidence is the difference between the predicted math score and the achieved score. Thus, a subject whose prediction is higher than her actual score is called overconfident, and a subject whose prediction is below her actual score is called underconfident. 


\section{Details}

Questions Description

Word fluency I would like you to name as many different animals as you can in 60 seconds.

Numeracy Q.1 What is $45+72$ ?

Numeracy Q.2 You have 4 friends and you want to give each friend four sweets.

How many sweets do you need?

Numeracy Q.3 What is $5 \%$ of 200 ?

Numeracy Q.4 You want to buy a bag of rice that costs 270 Baht, You only have one 1000 Baht note. How much change will you get?

Numeracy Q.5 In a sale, a shop is selling all items at half price.

Before the sale a mattress costs 3000 Baht.

How much will the mattress cost in the sale?

Numeracy Q.6 A second-hand motorbike dealer is selling a motorbike for 12000 Baht. His is two thirds of what it costs new.

How much did the motorbike cost new?

Overconfidence How many of the 6 math's questions above, do you think you have answered correctly? 


\section{Appendix}

\section{Conceptual Framework}

We present our conceptual framework that explores the relationship between the choice of money $m$, the individual choice of a tasty treat $t t$ and the groups choice of $\bar{t}$. In this section, we ignore the effect of individual preferences as denoted by $x$ and $\bar{x}$ in this paper. We can justify this as we are conducting an experiment and due to personal preferences being the same across treatments. Hence each participant's utility function is defined as:

$$
U(t t, m ; D, \overline{t t})=u(t t, m)-D \cdot c(t t-\bar{t} t)
$$

The first component $u(t t, m)$ is both increasing and concave in both $t t$ and $m$. It represents the utility that an individual receives from choosing the $t t$ or $m$, whereas the choice in $t t \in\{0,1\}$ and $m \in\{10, \ldots, 70\}$. Because individuals have to decide between $t t$ and $\mathrm{m}, t t=1$ implies $m=0$ and $m>0$ implies $t t=0$. Also note that the difference $u(0, m)-u(1,0)$ is increasing in $m$ : the higher $m$, the smaller the share of individuals that will prefer tasty treat to money, i.e.

$$
\frac{\partial \operatorname{Pr}(t t \succ m \mid D)}{\partial m}<0
$$

The utility function above includes a conformity cost function $c(t t-\overline{t t}) \geq 0$. This cost function is increasing, the larger the difference between own choice $t t$ of the respondent and average consumption of the peer group $\bar{t} t$.

$$
c(t t-\overline{t t}) \begin{cases}>0 & \text { if } t t \neq \overline{t t} \\ =0 & \text { if } t t=\overline{t t}\end{cases}
$$

In this model we do not go into the source of this cost. In our view there could be a number of reasons behind this, which we discussed in this paper. More importantly note that this conformity cost only applies to those individuals that play in a group. In the case of the experiment in the control group $D=0$, the conformity cost function should not play a role. In single 
treatment, the $t t$ is preferred if

$$
u(1,0)>u(0, m) .
$$

In the group treatment, $t t$ is chosen if

$$
u(1,0)-c(1-\bar{t} t)>u(0, m)-c(0-\bar{t})
$$

As participants possess the same utility function $U()$, average peer tasty treat consumption $\bar{t}$ must also be decreasing in $m$. Therefore, $\frac{\partial c(1-\bar{t} t)}{\partial m}>0$ and $\frac{\partial c(0-\bar{t} t)}{\partial m}<0$. In other words the conformity cost of choosing $t t$ increases the larger $m$ is. It should be noted that $\bar{t} t$ also depends on $t t$ and is therefore endogenous. Since choosing the $t t$ is synonymous with not choosing $m$, it is easier to think of a cost function that looks at the cost of choosing $t t$ at different levels of $m$. In this case the cost of choosing $t t$ would be positive for high values of $m$, but negative for low $m$. Figure C.1 shows the relationship between $m, \operatorname{Pr}(t t)$ and $c(1-\bar{t})$. 


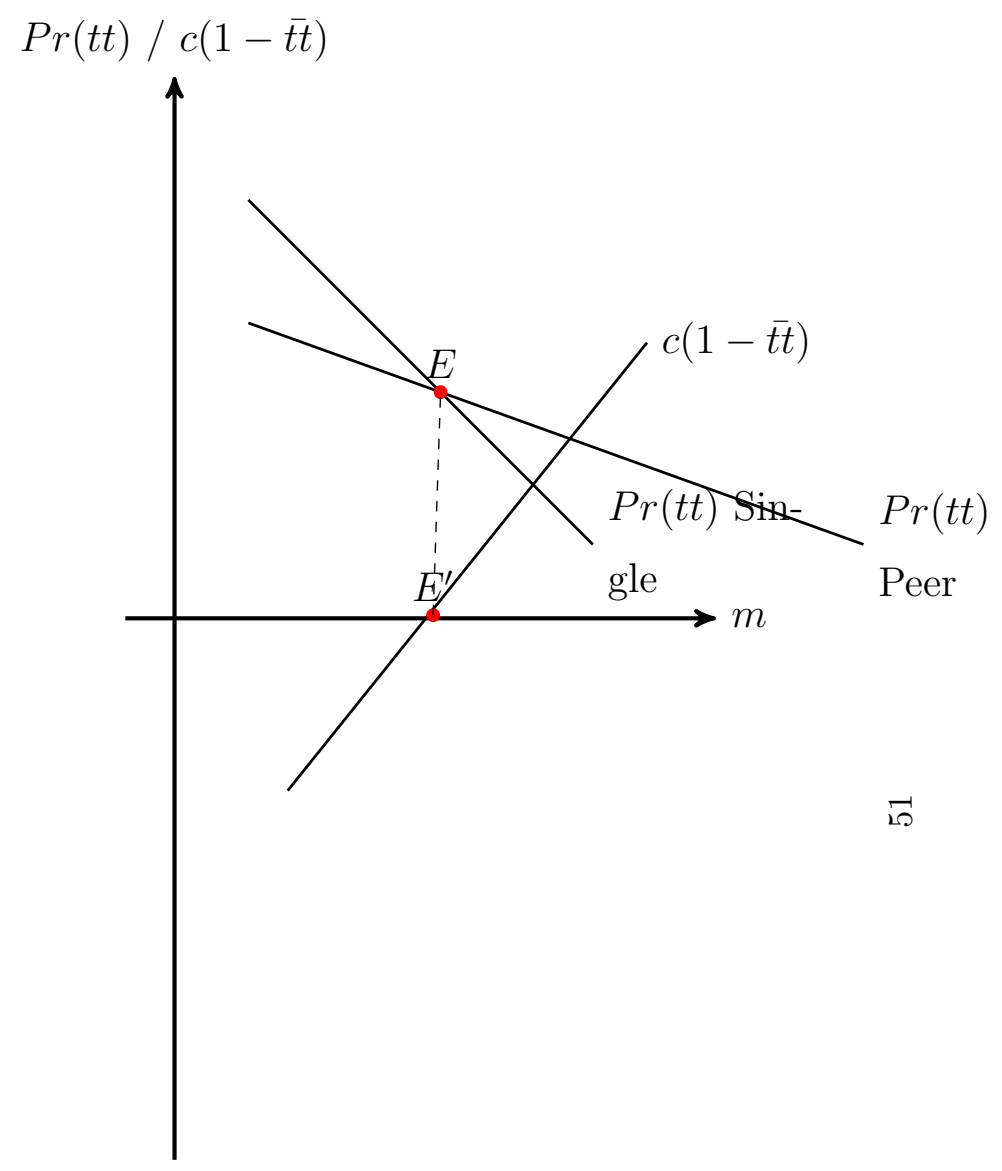

At point $\mathrm{E}$ the conformity cost for those that played with peer observation is 0 . They, therefore, make the same decision on average as those that play without peer observation. It becomes clear from Figure C.1 that the respondents under peer treatment react more strongly to a change in $m$ than respondents under single treatment

$$
\frac{\partial \operatorname{Pr}(t t \succ m \mid D=0)}{\partial m}<\frac{\partial \operatorname{Pr}(t t \succ m \mid D=1)}{\partial m} .
$$

Intuitively, this seems logical as there in an extra benefit from choosing the $t t$ when $m$ is small and an extra cost in choosing $t t$ when $m$ is large. This means that in the peer treatment, we expect that fewer people switch from $m$ to $t t$ at an early or late stage. In turn, we expect this to lower standard deviation within a group. So far we have shown the different reactions of $t t$ to a change in $m$, between the peer and the single treatment. We now need to show that the aforementioned conformity cost leads to a positive relationship between $t t$ and $\bar{t} t$ which can be defined as peer effects. From the original utility function 
we can see that

$$
\frac{\partial \operatorname{Pr}(t t \succ m \mid D=0)}{\partial \bar{t} t}=0
$$

Hence there is no change in $t t$ as $\bar{t} t$ change in the single treatment. Whereas under peer treatment

$$
\frac{\partial \operatorname{Pr}(t t \succ m \mid D=1)}{\partial \bar{t} t}>0
$$

There is a positive relationship between the number of people that choose $t t$ and the average peer decision $\bar{t}$.

As previously mentioned there are two conclusions arising from including a conformity cost function into a standard utility function. Firstly, as there is a cost involved with not doing what everyone also is doing, we expect there to be fewer extreme choices under peer observationi? At the same time, we expect there to be a clear positive relationship between $t t$ and $\bar{t}$ when the experiment is performed under peer observation, but not when the experiment is performed alone. 


\section{Appendix \\ Robustness Tables}

We firstly investigate whether morning or afternoon sessions would have a confounding effect on the demand of consumption good. We create an dummy variable for the morning session and interaction terms thereof with the group average excluding the individual and include this in our regression analysis (see Table D.1). We only look at those that played in observing peer groups. We find that there is no difference between results the game is played in the morning. Hence, main results of Table 6, remain unchanged. It is interesting to see whether the experimental session influences the results. In each village, we played two sessions. We find that whether the experiment was performed in the first or the second session does not make a difference to the results (see Table D.1. Taking the entire or merely the observing groups, we find that regardless whether one group played before the other, peer observation seems to have an impact on the consumption choice of the individual. Lastly, most of our groups contained five people, however it was not always possible to get five people together. We also check if group size has an effect on our results. In order to this we exclude all groups that did not contain five people. Again, we find that results do not change. 
Table D.1: Robustness, Morning, Experimental Sessions, Group Size

\begin{tabular}{lcccc}
\hline \hline & $\begin{array}{c}(1) \\
\text { Last row TT } \\
\text { Peer }\end{array}$ & $\begin{array}{c}(2) \\
\text { Last row TT } \\
\text { Peer }\end{array}$ & $\begin{array}{c}\text { Lost row TT } \\
\text { Last } \\
\text { Peer }\end{array}$ & $\begin{array}{c}(4) \\
\text { Last row TT } \\
\text { Peer }\end{array}$ \\
\hline Group Mean without Self & $0.58^{* * *}$ & $0.39^{*}$ & $0.62^{* * *}$ & $0.59^{* * *}$ \\
& $(0.13)$ & $(0.21)$ & $(0.12)$ & $(0.17)$ \\
Morning Dummy & -0.36 & -1.47 & & \\
Morning*Peer & $(0.35)$ & $(0.93)$ & & \\
Session 1 Dummy & & 0.37 & & -0.43 \\
& & $(0.25)$ & -0.21 & $(0.53)$ \\
Session 1*Peer & & & $(0.27)$ & 0.08 \\
& & & & $(0.17)$ \\
Group Average Controls & Yes & Yes & Yes & Yes \\
Individual Characteristics & Yes & Yes & Yes & Yes \\
\hline R-Squared & 0.29 & 0.30 & 0.30 & 0.30 \\
Observations & 264 & 203 & 197 & 197 \\
\hline
\end{tabular}

This table reports regression results with standard errors in parenthesis. ${ }^{* * *}, * *$ and $*$ denote significance at the $1 \%, 5 \%$ and $10 \%$ levels, respectively. Morning dummy is a dummy that is one if the experiment was performed in the morning, Session 1 Dummy is a dummy that is one if the experiment was performed during the first experimental session in a village, the last column shows results for groups with five members only 